\title{
Unravelling the phylogeny of the root-hemiparasitic genus Odontites (tribe Rhinantheae, Orobanchaceae): Evidence for five main lineages
}

\author{
Daniel Pinto-Carrasco, ${ }^{1}$ Agnes Scheunert, ${ }^{2}$ Günther Heubl, ${ }^{2}$ Enrique Rico ${ }^{1}$ \& \\ M. Montserrat Martínez-Ortega ${ }^{1}$ \\ 1 Departamento de Botánica, University of Salamanca, Av. Licenciado Mendez Nieto s/n, and Biobanco de ADN Vegetal, Banco \\ Nacional de ADN, Edificio Multiusos I+D+i, C/ Espejo s/n, 37007 Salamanca, Spain \\ 2 Systematic Botany and Mycology, Department Biology I, and GeoBio-Center LMU, Ludwig-Maximilians-University, Menzinger \\ Strasse 67, 80638 Munich, Germany \\ Author for correspondence: Daniel Pinto-Carrasco, dpintocarrasco@usal.es \\ ORCID DPC, http://orcid.org/0000-0001-8534-3157; AS, http://orcid.org/0000-0001-7188-8797; ER, http://orcid.org/0000-0003-1769- \\ 0426; MMMO, http://orcid.org/0000-0002-3887-2416 \\ DOI https://doi.org/10.12705/664.6
}

\begin{abstract}
Despite the recent publication of several phylogenies focused on Rhinantheae, which has been expanded to include three Asian endemic genera, few studies so far have dealt with particular genera within the tribe. Here, we focus on Odontites and related genera because of the high morphological variability of the group and its unclear generic boundaries. Phylogenetic analyses were performed for nrDNA (ITS) and cpDNA (trnK region and rpsl6 intron) datasets, using Bayesian and Parsimony analyses. Our results cast doubt on the inclusion of Pterygiella and related genera within the Rhinantheae and support the paraphyly of Phtheirospermum, making it necessary to propose three new combinations to avoid it. Odontites is recircumscribed to include Bartsiella, Bornmuellerantha, and Macrosyringion, but not Odontitella. Within Odontites, five distinct lineages are identified. These are distinguishable either by morphological synapomorphies or by a combination of several character states. Most of the Odontites species are regarded as monophyletic. In the O. vernus and O. luteus complexes, some taxonomic changes are made to avoid paraphyly, which results in three new combinations.
\end{abstract}

Keywords Odontites and related genera; Phtheirospermum; phylogenetic incongruence; Pterygiella complex; Rhinantheae; species monophyly

Supplementary Material Electronic Supplement (Appendix S1; Fig. S1) and DNA sequence alignment files are available in the Supplementary Data section of the online version of this article at http://ingentaconnect.com/content/iapt/tax

\section{INTRODUCTION}

Traditionally, all root-parasitic Scrophulariaceae (today considered part of Orobanchaceae; Young \& al., 1999; Bennett \& Mathews, 2006; McNeal \& al., 2013) have been included in tribe Rhinantheae. The data available to date show that this tribe is not monophyletic. However, a subgroup of 15-20 genera (depending on different taxonomic treatments) forms a natural group, which includes the type genus Rhinanthus L. ("Bartsia clade" in Wolfe \& al., 2005, or "Clade V" in Bennett \& Mathews, 2006 and McNeal \& al., 2013). Tribe Rhinantheae has recently been redefined as the "least inclusive crown clade that includes: Pterygiella nigrescens Oliv. 1896, Rhinanthus crista-galli L. 1753, Melampyrum pratense L. 1753, and Tozzia alpina L. 1753" (McNeal \& al., 2013). This tribe has been the focus of four phylogenetic studies. The first two (Těšitel \& al., 2010; Scheunert \& al., 2012) improved the taxon sampling and filled sampling gaps. They corroborated the monophyly of the tribe, identified major lineages within it, and proposed some taxonomic changes including new nomenclatural combinations.
Later on, Uribe-Convers \& Tank (2015) and Gaudeul \& al. (2016) investigated the diversification dynamics and biogeography of Bellardia All. s.l. (including Bellardia, Parentucellia Viv., and Neobartsia Uribe-Convers \& Tank; "Bellardia clade" in Scheunert \& al., 2012) and Odontites Ludw., respectively, and made use of the phylogeny of Rhinantheae only as an evolutionary framework. None of these studies included samples of the endemic Chinese genus Pterygiella Oliv. or of the related genera Phtheirospermum Bunge ex Fisch. \& C.A.Mey., Xizangia D.Y.Hong and Pseudobartsia D.Y.Hong. Apart from investigations at tribal level, there are few molecular studies on particular genera of the Rhinantheae (Euphrasia L., Gussarova \& al., 2008; the "Pterygiella complex", Dong \& al., 2013; Neobartsia, Uribe-Convers \& Tank, 2015; Uribe-Convers \& al., 2016).

Figure 1 summarizes the phylogenetic hypotheses of the "core group of Rhinantheae" (sensu Scheunert \& al., 2012) proposed so far (Těšitel \& al., 2010; Scheunert \& al., 2012; McNeal \& al., 2013; Uribe-Convers \& Tank, 2015; Gaudeul \& al., 2016). In most of them, Odontites (including Bornmuellerantha Rothm.) was deemed sister to the Bellardia clade in cpDNA and

Received: 23 Sep 2016 | returned for (first) revision: 24 Nov 2016 | (last) revision received: 29 Mar 2017 | accepted: 31 Mar 2017 || publication date(s): online fast track, n/a; in print and online issues, 18 Aug 2017 || (C) International Association for Plant Taxonomy (IAPT) 2017 
combined datasets (nrDNA+cpDNA). Only Scheunert \& al. (2012) and Gaudeul \& al. (2016) included samples of Bartsiella Bolliger, Macrosyringion Rothm. and Odontitella Rothm. in their studies. Scheunert \& al. (2012) found Odontitella to be sister to Nothobartsia Bolliger \& Molau, supporting its segregation from Odontites. In Scheunert \& al. (2012) and Gaudeul $\&$ al. (2016), Bartsiella and Bornmuellerantha were nested within Odontites s.str. (sensu Bolliger, 1996), and both genera were consequently re-included in it. Following Scheunert \& al. (2012), the position of Macrosyringion remained doubtful due to topological incongruence and low clade support (in the
cpDNA tree). Gaudeul \& al. (2016) did not detect the same relationships at the genus level as previous authors did, probably due to limited taxon sampling (Nothobartsia, Neobartsia, and Hedbergia Molau were not included). This latter study found Macrosyringion as sister to the clade containing Bellardia and Parentucellia with high support.

Odontites (with ca. 30 species and 15 subspecies in its traditional and broadest sense, hereafter referred to as Odontites s.l.; Bolliger, 1993) is distributed throughout temperate Eurasia, the Mediterranean region (including several islands), and Macaronesia, with a diversification centre in the Western
Combined

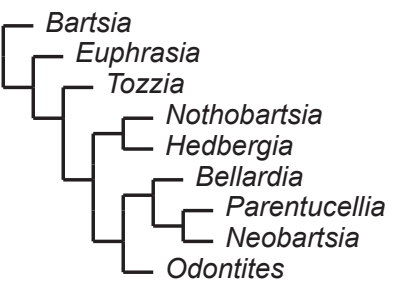

Scheunert \& al. (2012)

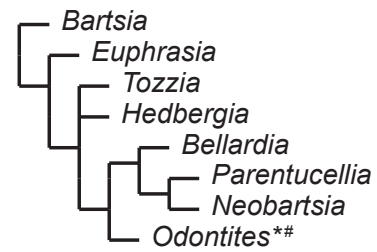

McNeal \& al. (2013)
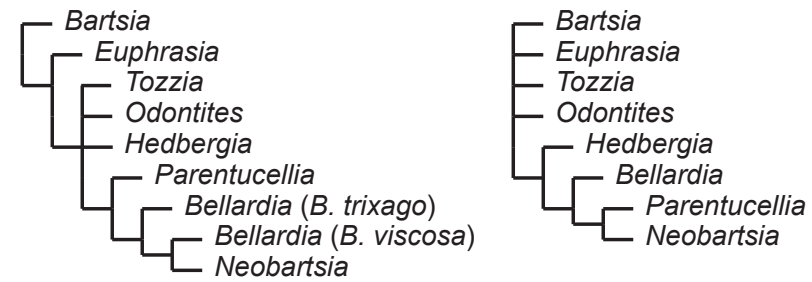

Uribe-Convers \& Tank (2015)
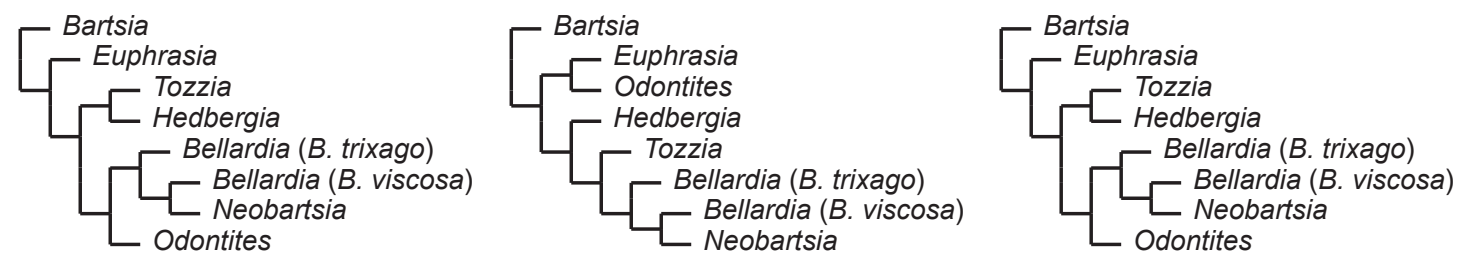

Gaudeul \& al. (2016)
nrDNA

cPDNA
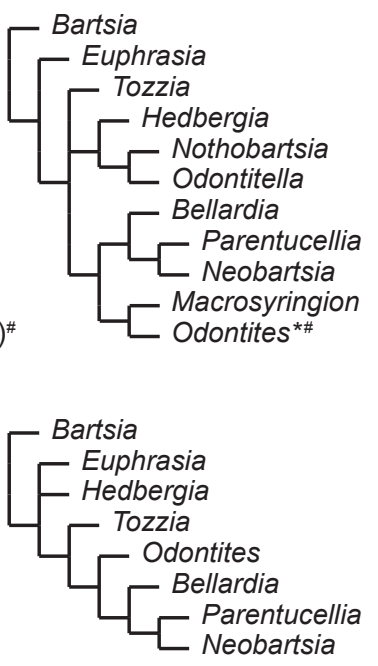

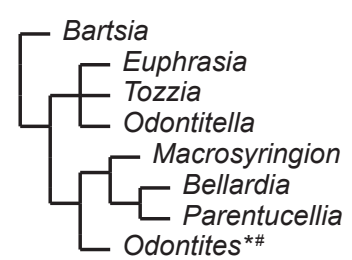

Fig. 1. Summary of the tree topologies obtained from the nrDNA, cpDNA and combined datasets published in the most relevant studies of tribe Rhinantheae (redrawn from Těšitel \& al., 2010; Scheunert \& al., 2012; McNeal \& al., 2013; Uribe-Convers \& Tank, 2015; and Gaudeul \& al., 2016). Trees were pruned to only show the "core group of Rhinantheae" (sensu Scheunert \& al., 2012), and branches with low support were collapsed into polytomies. Clades containing Bartsiella and Bornmuellerantha samples were marked with* and * respectively. 
Mediterranean area. Its taxonomy has long been controversial. Linnaeus (1753) described several species of Odontites under Euphrasia, and later taxonomists added newly discovered species and proposed several rearrangements (e.g., Don, 1838; Kerner, 1888; Beauverd, 1911). Most recently, Rothmaler (1943) segregated Bornmuellerantha, Macrosyringion, and Odontitella from Odontites s.1. The remaining species were divided into three sections based on the morphology of the corolla and stamens (sect. Dispermotheca (Beauv.) Rothm., sect. Orthantha Benth. em. Rothm., sect. Euodontites Benth. em. Rothm.). Although this proposal was not considered by Webb \& Camarasa (1972), Bolliger (1996) recognized the three small genera segregated by Rothmaler (1943), and even separated an additional genus, Bartsiella, based on pollen exine sculpturing and calycinal glandular hairs (Bolliger, 1985; Bolliger \& Wick, 1990). Bolliger (1996) included 26 species in Odontites s.str. and did not accept sections within the genus, although several species groups were recognized. Most are present in the Iberian Peninsula (Rico, 2009), and recently this area has been postulated as the centre of origin of a clade composed of Odontites s.str., Bartsiella, and Bornmuellerantha (Gaudeul \& al., 2016).

Morphologically, Odontites s.1. has character states which are intermediate between those of Euphrasia and Bartsia L. (Bolliger, 1996). Marked morphological variability exists within Odontites s.l., especially regarding corolla shape and colour, as well as calyx and corolla indument (Fig. 2). Many vegetative and reproductive characters appear to have undergone parallel, convergent, and reverse evolution (Bolliger, 1993). Furthermore, some morphological characters and phenology are influenced by host plants (Snogerup, 1982), and in some species groups seasonal ecotypes exist (ter Borg, 1985; Bolliger, 1996; Koutecký \& al., 2012). Therefore, the delimitation of species and the analysis of species relationships are difficult when based only on morphology.

Hybridization and incomplete lineage sorting (ILS) are the most widely studied processes that might explain gene-tree incongruence (Kubatko, 2009). Hybridization events can also result in allopolyploid speciation; recurrent formation of polyploids in plants has been shown to be the rule rather than the exception (Soltis \& Soltis, 1993, 1999). However, other biological processes (e.g., gene duplication and horizontal gene transfer) may also be a source of phylogenetic incongruence. Regarding the members of tribe Rhinantheae, several cases of incongruence between gene trees involving several genera, (e.g., the clade Odontitella + Nothobartsia; Scheunert \& al., 2012), individual genera (e.g., Tozzia L. or Odontites; Uribe-Convers \& Tank, 2015) and species within genera (e.g., Bartsia sp.; Scheunert
$\&$ al., 2012) have been detected. Polyploidization is not extensive within Odontites s.1., although two taxa, O. jaubertianus (Boreau) D.Dietr. and O. vernus (Bellardi) Dumort. subsp. vernus, could be the result of allo- and autopolyploidization, respectively (Bolliger \& al., 1990; Bolliger, 1996).

The aims of this study were to: (1) test the monophyly and topological position of Odontites, using a complete phylogenetic framework (i.e., all genera included in tribe Rhinantheae sensu McNeal \& al., 2013); (2) determine the usefulness of several morphological characters considered relevant in previous taxonomic treatments in delimiting and supporting monophyletic groups, especially in Odontites and related genera; and (3) finally, test the monophyly of those species in the Odontites clade for which more than one specimen was collected, covering the entire species distribution range.

\section{MATERIALS AND METHODS}

Plant material. - Taxon sampling covered a representative number of species of all genera included in tribe Rhinantheae (clade V+Pterygiella complex; McNeal \& al., 2013). A total of 350 ingroup individuals (747 newly generated sequences) were included in the analyses. They represent 86 species of 17 genera. For correct choice of outgroup taxa, the most comprehensive molecular phylogeny of Orobanchaceae to date (McNeal $\&$ al., 2013) was followed. One representative species of tribe Buchnereae Benth. (Striga asiatica (L.) Kuntze; clade VI) together with three of tribe Pedicularideae Duby (Seymeria laciniata (M.Martens \& Galeotti) Standl., Pedicularis groenlandica Retz. and Phtheirospermum japonicum (Thunb.) Kanitz; clade IV) were chosen to root the phylogenetic analyses. All sequences used in the study (from GenBank and newly generated data with voucher information) are listed in Appendix 1. The keys provided by Bolliger (1996) and Rico (2009) were used to identify most of the herbarium vouchers used here. Seven species belonging to Odontites s.str., which are narrowly endemic in North Africa (Algeria and Tunisia; 5 spp.), Sicily (1 sp.), and the Near East (Lebanon and Syria; $1 \mathrm{sp}$.), were not included in this study because it was not possible to obtain good-quality DNA samples.

DNA extraction and amplification. - Total genomic DNA was isolated either from silica-gel-dried tissue (leaves and/or bracts) or from herbarium samples using the modified CTAB method (Doyle \& Doyle, 1987) or the NucleoSpin Plant Kit following the protocols of the manufacturer (MachereyNagel, Düren, Germany). DNA was diluted in $50 \mu$ l of buffer.

Fig. 2. Morphological diversity in Odontites. Herbarium number or locality are indicated in parentheses. A-C, Macrosyringion lineage; D, Bornmuellerantha lineage; E \& F, Pyrenaeus lineage; G-M, Viscosus lineage; N-Q, Vernus lineage. A, O. longiflorum (Spain, Burgos, Montes Obarenes); B, O. longiflorum (SALA 135639; detail of calyx and corolla indument); C, O. longiflorum (SALA 110071; variability in corolla colour); D, O. aucheri (SALA 120807); E, O. cebennensis (SALA 156186); F, O. cebennensis (SALA 135679; detail of calyx and corolla indument); G, O. foliosus (SALA 134537); H, O. bolligeri (SALA 142142, detail showing a glabrous corolla); I, O. rameauanus (MA 746138); J, O. maroccanus (SALA 156178); K, O. viscosus (SALA 137360); L \& M, O. viscosus (SALA 110047 and SALA 137373; variability in corolla colour); N, O. vernus (SALA 135643); 0, O. vernus (Spain, Valladolid, San Miguel del Arroyo; detail of calyx and corolla indument); $\mathbf{P}$, O. luteus (SALA 135662); Q, O. hollianus (MA 714540). — Photographs by S. Andrés-Sánchez (A, H, L), D. Pinto-Carrasco (B, C, E, J), E. Rico (D, F, G, I, K, $\mathrm{M}, \mathrm{N}, \mathrm{P}, \mathrm{Q})$ and J. Bobo-Pinilla (O). 

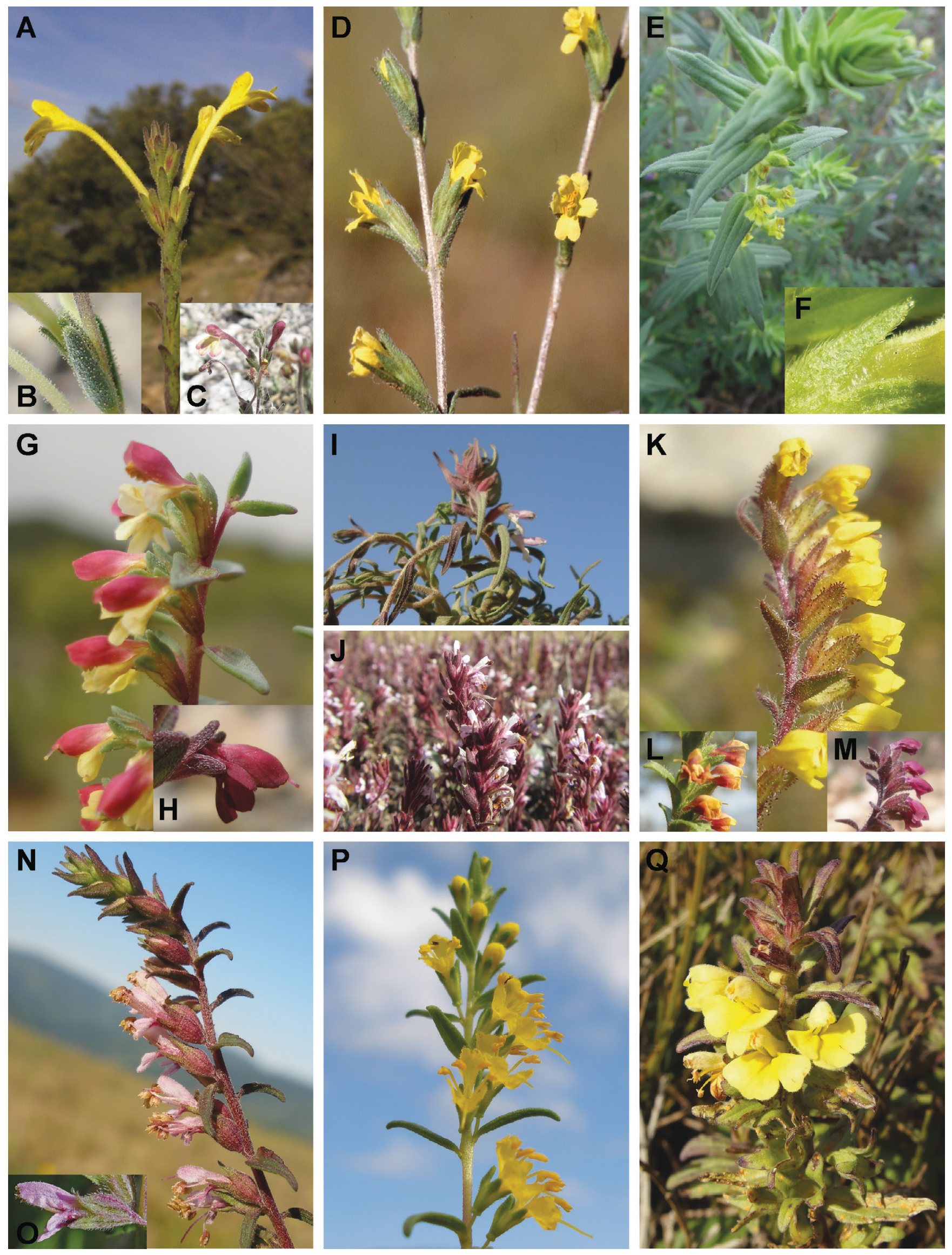
Concentration and quality were assessed by spectrophotometry and electrophoresis (1.0\% agarose gel), respectively. One nuclear ribosomal region (including the ITS1 and ITS2 spacer regions and the 5.8S rRNA gene) plus two non-coding chloroplast regions (part of the $\operatorname{trn} K$ region and the $r p s 16$ intron) were chosen for phylogenetic analyses. Reagent concentrations, PCR profiles, and primers followed Scheunert \& al. (2012). Most of the markers were sequenced bidirectionally with the same primer pairs as used for amplification, using BigDye chemistry on an ABI 3730XL analyzer at Macrogen Europe or at LudwigMaximilians-University sequencing services.

Sequence editing, alignment, and indel-coding. - All newly generated sequences were edited, assembled, and automatically aligned using Geneious v.5.5.8 (Kearse \& al., 2012). Online available sequences completing taxon sampling were taken mainly from Těšitel \& al. (2010), Scheunert \& al. (2012), Dong \& al. (2013) and Uribe-Convers \& Tank (2015). They were trimmed to fit the length of the newly generated sequences and added to the alignments. Some minor adjustments were made manually after visual inspection, and mononucleotide repeats ( $\geq 5 \mathrm{bp}$ ) were excluded from further analysis. Insertions and deletions (indels) were coded according to the simple indel-coding method (Simmons \& Ochoterena, 2000), as implemented in SeqState v.1.4.1 (Müller, 2005). They were added to the data as a binary matrix and, consequently, gaps were treated as missing data.

Datasets and phylogenetic analyses. - Two datasets were analysed independently: (1) nrDNA (ITS) and (2) cpDNA (trnK $+r p s 16$ ). Since both soft and hard (posterior probabilities [PP] $\geq 0.80$ and $\geq 0.95$ respectively) topological incongruences between nrDNA and cpDNA trees were detected (see the paragraph "Visualization of topological incongruence" below), analyses using a combined dataset were not performed.

Phylogenetic analyses were conducted using both Bayesian inference (BI) and maximum parsimony (MP). Bayesian analyses were performed with MrBayes v.3.2 for 64-bit systems (Ronquist \& al., 2012), using the best substitution model for each sequenced region identified using the BIC criterion as implemented in jModeltest v.2.1.4 (Darriba \& al., 2012). The indel partitions were treated as restriction data and analysed using the model settings recommended by Ronquist \& al. (2009). Short preliminary runs were carried out with different hot chain temperatures (in the range 0.01-0.2) to check for swapping efficiency among chains. For the final analyses, the temperature parameter was fixed to temp $=0.025$. Two Markov chain Monte Carlo (MCMC) runs with four chains each (one cold chain, three hot chains) were started from independent random seeds and computed 10 million generations, with trees sampled every 1000th generation. After discarding a burn-in of 3000 trees (30\% of all sampled trees) from each run, a majority-rule consensus tree was calculated. Traces were visually inspected in Tracer v.1.6 (Rambaut \& al., 2015) to ensure that the effective sample sizes (ESSs) of all parameters were $>200$, as recommended by the authors, and to check the convergence of parameter estimates across runs. Nodes with PP $\geq 0.95$ were considered to be strongly supported (Huelsenbeck \& Rannala, 2004).
Parsimony analyses were conducted with TNT (Tree analysis using New Technology) v.1.1. (Goloboff \& al., 2008), applying the traditional search option (TBR, Tree BisectionReconnection branch swapping) with equal character weights. In an initial run, 10,000 random addition sequence replicates were performed, using TBR branch-swapping and saving 10 trees per replicate. Since some replicates reached the maximum number of saveable trees, the trees from the first run were used as starting trees in a second heuristic search. Bootstrap support (BS) was calculated with 1000 replicates, each consisting of 500 random addition sequence replicates using TBR branch-swapping (saving 100 trees per replicate) in PAUP* v.4.0b10 (Swofford, 2002). BS values $\geq 70$ were considered to indicate good node support (Hills \& Bull, 1993). Consistency index $(\mathrm{CI})$, retention index $(\mathrm{RI})$, and rescaled consistency index (RC) were likewise calculated using PAUP*.

Visualization of topological incongruence. - To represent the differences between trees obtained with differently inherited markers (biparental vs. maternal, i.e., ITS vs. cpDNA) as a network, network building algorithms were run using the corresponding consensus trees. As a means of maintaining only statistically robust nodes, those with $\mathrm{PP}<0.80$ in majority-rule consensus trees from the Bayesian analysis were collapsed using Mesquite (Maddison \& Maddison, 2014). Using this relatively low threshold, soft and hard incongruences can be shown at the same time. Collapsed trees were imported into SplitsTree v.4 (Huson \& Bryant, 2006). The SuperNetwork algorithm was run with the Edge Weights option set to none (branch lengths are not taken into account). The network was not rooted in order to avoid graphical distortion.

\section{RESULTS}

Sequencing and alignments. - For this study, a total of 747 sequences was generated: 248 for ITS, 249 for the rps16 intron, and 250 for the $\operatorname{trn} K$ region. As most of the ITS sequences provided unambiguous pherograms (i.e., without any signs of length polymorphisms), no cloning was performed, and, when required, single nucleotide polymorphisms were coded as IUPAC Nucleotide Codes. In addition to the newly generated sequences, 247 sequences were taken from GenBank (http://www.ncbi.nlm.nih.gov) to complete the taxon sampling. Table 1 summarizes details of alignment statistics for all markers and datasets including the proportions of parsimonyinformative characters and the models of molecular evolution.

The topology of the 50\% majority-rule consensus trees from the maximum parsimony and Bayesian analyses proved almost identical and differed only in the topology of some nodes that were poorly supported. As Bayesian trees were generally better resolved and supported, only the Bayesian topologies are shown. Bootstrap support derived from MP analyses were added to these trees.

Major clades in the ITS and cpDNA trees. - The topology of the cpDNA tree was generally similar to that of the ITS tree (Fig. 3; Electr. Suppl.: Fig. S1), but support values were overall slightly lower in the cpDNA tree. All genera were recovered as 
well supported clades (in one or both trees), with the exception of Phtheirospermum. The generitype species, Ph. japonicum, grouped within tribe Pedicularideae (sensu McNeal \& al., 2013; clade $\mathrm{A} ; \mathrm{ITS} P \mathrm{PP}=1 ; \mathrm{BS}=97, \operatorname{cpDNA} \mathrm{PP}=1 ; \mathrm{BS}=100$; Electr. Suppl.: Fig. S1), while the remaining three species formed a clade with Pterygiella $($ ITS PP $=1 ; \mathrm{BS}=100$, cpDNA PP $=$ $1 ; \mathrm{BS}=86$ ).

Comparing ITS and cpDNA topologies (Fig. 3; Electr. Suppl.: Fig. S1), only two cases (affecting six genera) of phylogenetic incongruence at generic or higher taxonomic levels were detected. These are visualized in a SuperNetwork (see below, Fig. 6A). The first is clade B (ITS PP $=0.93$; $\mathrm{BS}=86$, cpDNA PP $=1 ; \mathrm{BS}=51$; "Pterygiella complex II" sensu Dong $\&$ al., 2013; i.e., a clade composed of Pterygiella, Pseudobartsia and Xizangia) that was sister to tribe Rhinantheae s.str. (clades $\mathrm{C}-\mathrm{K}$ ) in cpDNA but related to tribe Pedicularideae (clade A) in ITS. The second concerns Euphrasia (clade H) and a clade that includes Odontitella and Nothobartsia (clade J). Euphrasia was part of a clade containing Hedbergia and Tozzia in ITS, but it was recovered as sister to clades $\mathrm{F}-\mathrm{K}$ in cpDNA. On the other hand, clade J (ITS PP $=1$; BS $=99$, cpDNA PP $=1$; BS =99) was sister to Hedbergia (clade F) in the cpDNA tree, but sister to Odontites s.l.+ Macrosyringion (clade K) in the ITS analysis $(\mathrm{PP}=0.94 ; \mathrm{BS}<50)$.

Tribe Rhinantheae s.str. (clades C-K; clade V in McNeal $\&$ al., 2013) was strongly supported in both analyses (ITS PP $=1 ; \mathrm{BS}=97$, cpDNA $\mathrm{PP}=1 ; \mathrm{BS}=93$ ). The branching pattern of clade C (Melampyrum), clade D ("RRL clade", composed of Rhinanthus, Lathraea L. and Rhynchocorys) and the "core group of Rhinantheae" (clades E-K) was identical to that in Scheunert \& al. (2012). Bartsia alpina L. (clade E) was the first-branching taxon within the core group of Rhinantheae. Leaving aside incongruent clades (clades $\mathrm{H}$ and $\mathrm{J}$ ), the remaining taxa were grouped into two clades in the ITS tree, the first containing Hedbergia and Tozzia (clades F and G), and the second grouping together the Bellardia and Odontites clades (clades I and K, respectively). All samples of Tozzia formed a clade (clade G; ITS PP =1; BS = 100; cpDNA PP =1; BS = 97). In the cpDNA tree, the position of Tozzia remained unresolved, as the branch that connected it with clade I-Bellardia plus clade K-Odontites had low support. Clade I-Bellardia was sister to clade $\mathrm{K}-$ Odontites in the $\mathrm{cpDNA}$ tree $(\mathrm{PP}=0.91$; $\mathrm{BS}=$ 54). Finally, all species of Odontites formed a clade (clade $\mathrm{K}$ ) in both analyses, but with low support in the cpDNA tree (ITS $\mathrm{PP}=1 ; \mathrm{BS}=95, \mathrm{cpDNA} \mathrm{PP}=0.71 ; \mathrm{BS}=61$ ).

Phylogenetic relationships among species of Odontites s.l. (clade K). - In the ITS tree, the clade K.2-Macrosyringion (grouping $O$. longiflorus and $O$. glutinosus) appeared nested within Odontites, but was recovered as sister to the remaining Odontites in cpDNA (Fig. 4, clade K.2; ITS PP $=1$; $\mathrm{BS}=100$; cpDNA PP $=1 ; \mathrm{BS}=100$ ). Five main lineages were detected in the ITS analysis, and confirmed in the cpDNA tree (Figs. 4, 5). Relationships among these five lineages remained unclear due to low support and short lengths of some internal branches, especially in the ITS analysis. The two species included in the K.1-Pyrenaeus clade $($ ITS PP $=1 ; \mathrm{BS}=100 ; \operatorname{cpDNA~PP}=1 ; \mathrm{BS}$ $=100)$, O. cebennensis H.J.Coste \& Soulié and O. pyrenaeus (Bubani) Rothm., were monophyletic according to the ITS tree. However, in the cpDNA tree, only the samples corresponding to the former were recovered as a clade, whereas the later formed a grade. The well-supported K.2-Macrosyringion clade was composed of two species, both recovered as monophyletic. In the K.3-Bornmuellerantha clade $($ ITS PP $=1$; $\mathrm{BS}=97$; cpDNA PP = $1 ; \mathrm{BS}=100$ ), it was not possible to test the reciprocal monophyly of its two species as only one sequence of $O$. alshehbazianus (Dönmez \& Mutlu) A.Fleischm. \& Heubl was analysed. The K.4-Viscosus clade contains a higher number of taxa compared to clades K.1 to K.3. The K.4 clade was monophyletic in the ITS tree $(\mathrm{PP}=1 ; \mathrm{BS}=95)$, but divided into two subclades in the cpDNA tree, with one being sister to the K.1-Pyrenaeus clade.

Table 1. Summary of sequence characteristics and analysis results for the different regions and datasets.

\begin{tabular}{|c|c|c|c|c|}
\hline & ITS & rps16 & $\operatorname{trn} K$ & cpDNA \\
\hline Number of individuals & 353 & 308 & 333 & 349 \\
\hline Taxon sampling: species (genera) & $87(21)$ & $65(19)$ & $75(20)$ & $83(20)$ \\
\hline Length of newly generated sequences in bp (average) & $577-734(695)$ & $524-861(826)$ & 676-1057 (1038) & - \\
\hline Aligned length in bp, after trimming & 797 & 952 & 1128 & 2080 \\
\hline Number of coded indels & 138 & 85 & 64 & 149 \\
\hline$\%$ total missing data & 6.3 & 3.3 & 3.0 & 10.7 \\
\hline Model of molecular evolution (Bayesian information criterion) & $\mathrm{SYM}+\mathrm{I}+\mathrm{G}$ & $\mathrm{TVM}+\mathrm{G}$ & $\mathrm{TVM}+\mathrm{G}$ & - \\
\hline No. of variable sites $(\%)$ & $579(61.9)$ & - & - & $949(42.6)$ \\
\hline No. of parsimony-informative sites (\%) & $483(51.7)$ & - & - & $621(27.9)$ \\
\hline Tree length of most parsimonious trees & 2123 & - & - & 1614 \\
\hline Consistency index (CI) & 0.4207 & - & - & 0.7127 \\
\hline CI excluding uninformative sites & 0.3931 & - & - & 0.6347 \\
\hline Retention index (RI) & 0.9203 & - & - & 0.9491 \\
\hline Rescaled consistency index (RC) & 0.3872 & - & - & 0.6764 \\
\hline
\end{tabular}


Fig. 3. Majority-rule consensus trees from the Bayesian analysis of tribe Rhinantheae ITS and cpDNA datasets, with branch support (PP/BS). Main clades are indicated with different letters. Clade names: A, Tribe Pedicularideae, B, Pterygiella Complex II, C, Melampyrum, D, RRL, E, Bartsia s.str., F, Hedbergia, G, Tozzia, H, Euphrasia, I, Bellardia, J, Nothobartsia-Odontitella, K, Odontites. Clades corresponding to genera were collapsed.
ITS

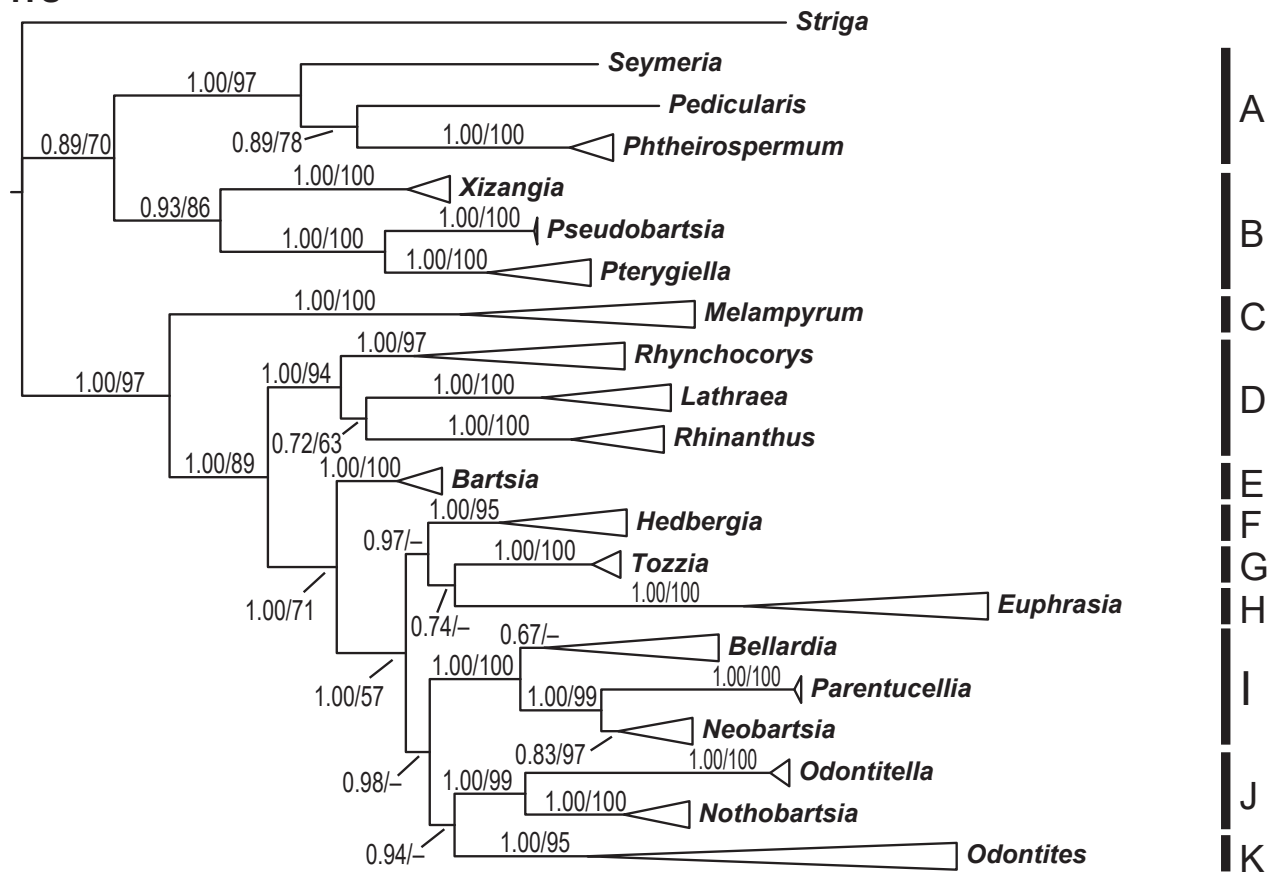

cpDNA

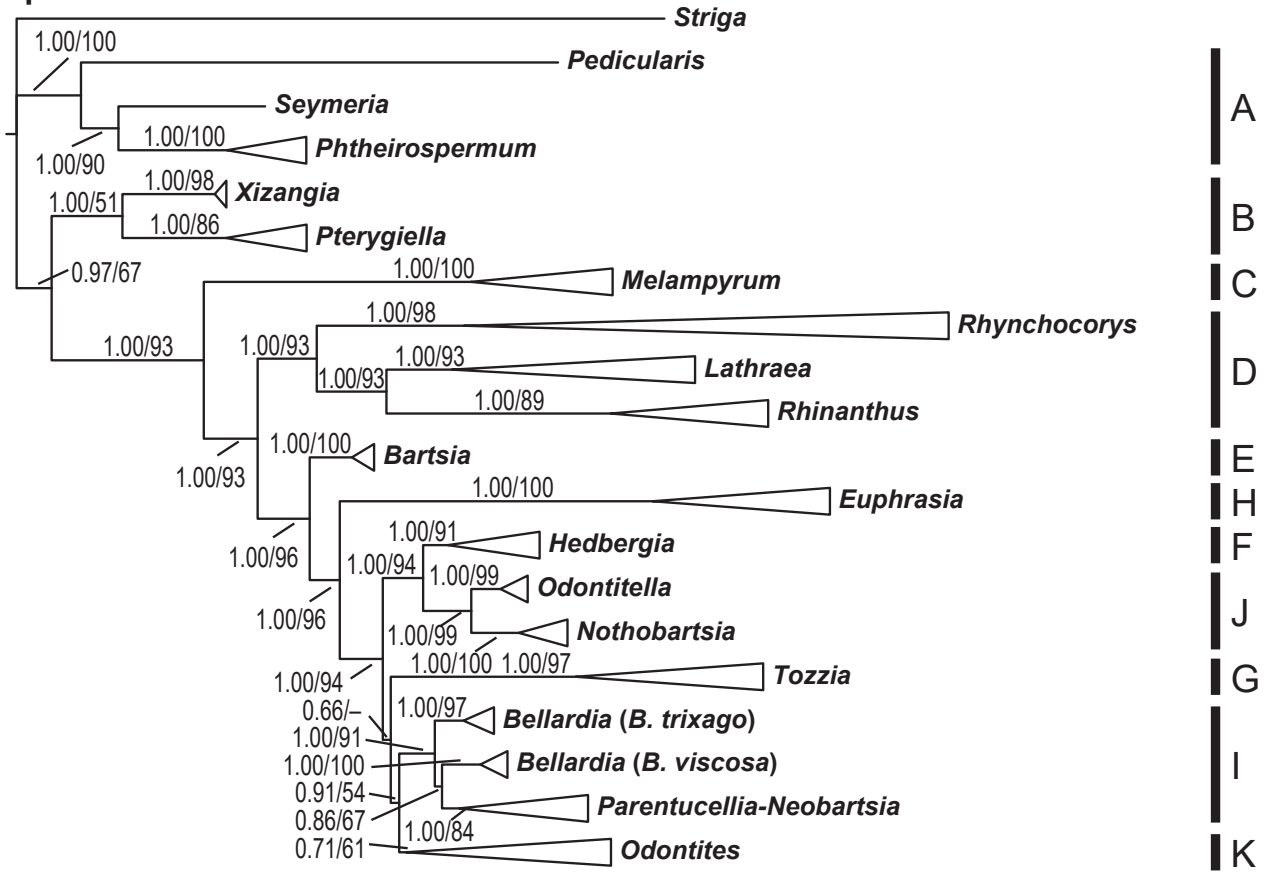

Fig. 4. Majority-rule consensus trees from the Bayesian inference analysis, with branch support (PP/BS), showing the main clades of Odontites and sister clades (J-Nothobartsia-Odontitella, I-Bellardia) based on ITS and cpDNA. Main lineages are indicated with different colours and letters. Clade names: K.1-Pyrenaeus, K.2-Macrosyringion, K.3-Bornmuellerantha and K.4-Viscosus. Clade K.5-Vernus was collapsed. Ma., Macrosyringion; O., Odontites; Synonyms: O. cyprius = O. linkii subsp. cyprius; O. glutinosus = Ma. glutinosum; O. longiflorus = Ma . longiflorum. 


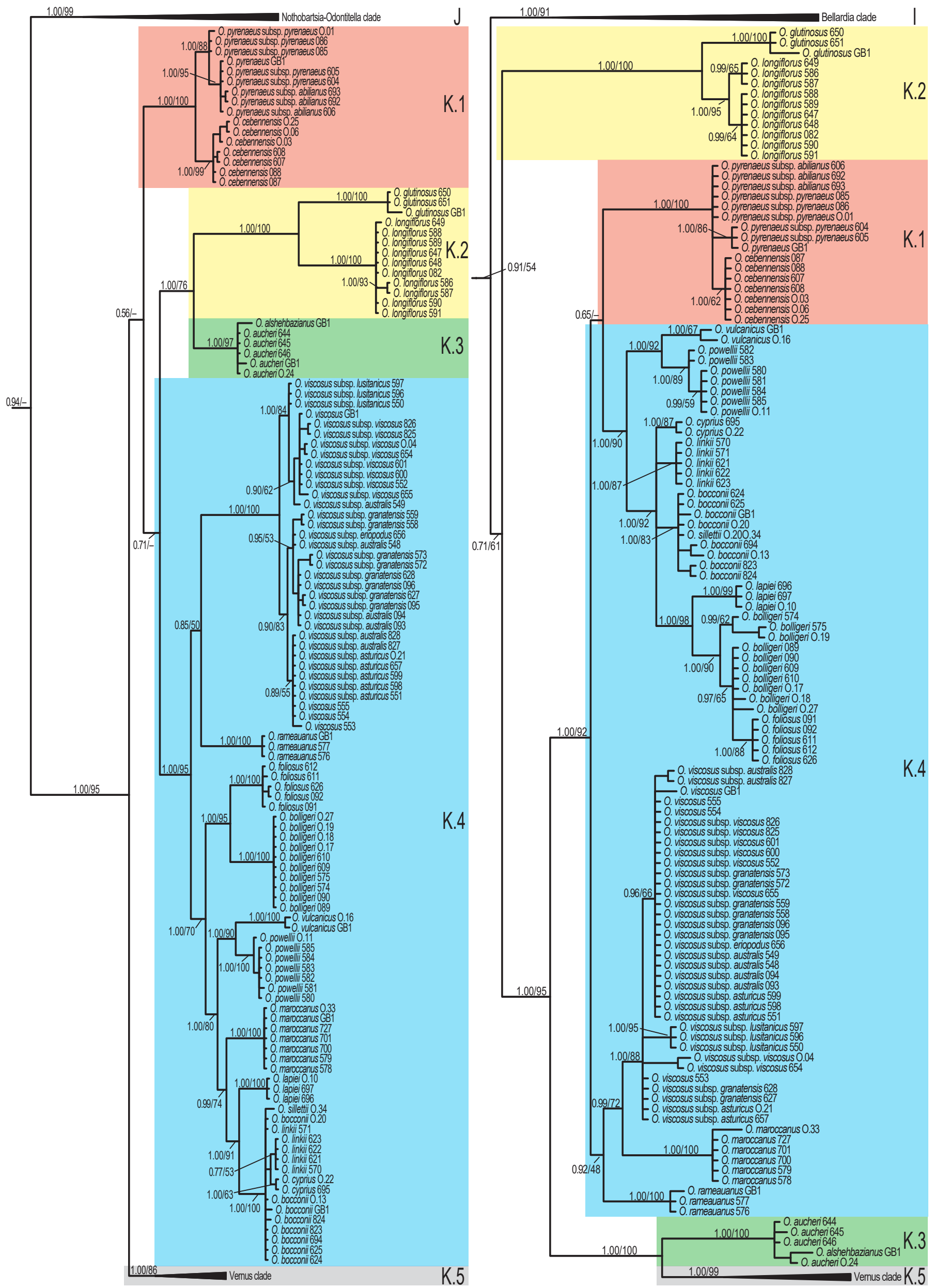


However, given that the branch that grouped K.1 with this K.4 subclade had low support ( $\mathrm{PP}=0.65 ; \mathrm{BS}<50$ ), the topologies of the two trees showed a soft incongruence and became compatible when a branch collapsing threshold of PP $<0.80$ was applied. Most of the species sampled of the K.4-Viscosus clade proved to be monophyletic (with two exceptions; i.e., O. bolligeri $\mathrm{E}$.Rico \& al. in the cpDNA tree, and the species belonging to the "Bocconii group" sensu Bolliger, 1996). Finally, of the large number of taxa in the K.5-Vernus clade (ITS PP $=1$; BS $=86$; $\mathrm{cpDNA}$ PP $=1$; $\mathrm{BS}=99)$, which have been described based on morphology, only four narrowly endemic species formed monophyletic groups: $O$. corsicus (Loisel.) G. Don. (in ITS only), O. hollianus (Lowe) Benth., O. kaliformis (Pourr. ex Willd.) Pau, and O. recordonii Burnat \& Barbey.

Several cases of topological incongruence were detected at both the intrageneric and interspecific levels. At the intrageneric level (Fig. 6A), the K.3-Bornmuellerantha clade was sister to the K.2-Macrosyringion clade in the ITS tree ( $\mathrm{PP}=1$; $\mathrm{BS}=76$ ), but sister to the K.5-Vernus clade in the cpDNA tree $(\mathrm{PP}=1 ; \mathrm{BS}=100)$. At the interspecific level, there were two cases of incongruence, both in the K.4-Viscosus clade (Fig. 6B). The first case concerned $O$. maroccanus Bolliger. It was sister to O. viscosus (L.) Clairv. in the cpDNA tree ( $\mathrm{PP}=0.99$; $\mathrm{BS}=72$ ), but sister to a clade containing O. lapiei Batt. and the Bocconii-linkii clade ( $\mathrm{PP}=0.99 ; \mathrm{BS}=74)$ in the ITS tree. The second incongruence concerned a clade that included two species: $O$. bolligeri and $O$. foliosus Pérez Lara. This clade was sister to O. lapiei in the cpDNA tree $(\mathrm{PP}=1 ; \mathrm{BS}=98)$, but part of a clade that included most of the North African and Central to Eastern Mediterranean species ( $\mathrm{PP}=1 ; \mathrm{BS}=70)$ in ITS.

\section{- DISCUSSION}

Delimitation of tribe Rhinantheae. - Here, the most comprehensive phylogeny of tribe Rhinantheae to date, including two or more samples of all recognized genera, is presented. All major clades revealed in previous ITS phylogenies were confirmed as well as most of the clades recovered in previous cpDNA studies (Scheunert \& al., 2012; Dong \& al., 2013; McNeal \& al., 2013; Uribe-Convers \& Tank, 2015; Gaudeul \& al., 2016). The monophyly of tribe Rhinantheae (sensu McNeal \& al., 2013, i.e., including the East Asian Pterygiella complex II) was not supported by our ITS tree, as the Pterygiella complex II was recovered as sister to tribe Pedicularideae (Fig. $3 \mathrm{~A}$, clades $\mathrm{B}$ and $\mathrm{A}$ respectively). In the cpDNA analysis, it was sister to Rhinantheae s.str., although both groups were separated by long branches (i.e., large genetic distances). This topological incongruence had previously been detected by McNeal \& al. (2013) and Zhou \& al. (2014), although they did not explicitly comment on it. McNeal \& al. (2013) even proposed a node-based definition of the Rhinantheae that omitted this finding. The monophyly of the Pterygiella complex II has been clearly demonstrated (Dong \& al., 2013), and the observed topological incongruence casts its inclusion in tribe Rhinantheae into doubt. Additionally, the members of this complex have at least two morphological characters that differentiate them from those of tribe Rhinantheae s.str. (clade $\mathrm{V}$ in McNeal \& al., 2013). First, they have a five-toothed instead of a four-toothed calyx as present in the Rhinantheae (Molau, 1988, 1990; Hong \& al., 1998; Benedí \& al., 2009). Second, all species in the Pterygiella complex II have pollen grains of types Ia-1 or IV (with granulate or regularly retipilate exine sculpturing, and a size of $<27 \mu \mathrm{m}$; Lu \& al., 2007), while in tribe Rhinantheae s.str. pollen grains have variable exine surfaces and sizes $>27 \mu \mathrm{m}$ (except in Tozzia; İnceoğlu, 1982; Minkin \& Eshbaugh, 1989; Bolliger \& Wick, 1990; Lu \& al., 2007). Further studies are necessary to shed light on the tribal placement of Pseudobartsia, Pterygiella and Xizangia, using an adequate selection of markers and samples.

Our results validate the polyphyly of Phtheirospermum, as already suggested by various authors (Dong \& al., 2013; McNeal \& al., 2013; Zhou \& al., 2014). The generitype species, Ph. japonicum (= Ph. chinense Bunge ex Fisch. \& C.A.Mey.), clustered within tribe Pedicularideae (clade A-Pedicularideae), but the other three species of Phtheirospermum formed a clade together with Pterygiella (clade B-Pterygiella complex II; see Fig. S1). As recommended by McNeal \& al. (2013), the most conservative option is to include $P h$. muliense C.Y.Wu \& D.D.Tao, Ph. parishii Hook.f., and Ph. tenuisectum Bureau \& Franch. in Pterygiella. The following new combinations are therefore required:

Pterygiella muliensis (C.Y.Wu \& D.D.Tao) Pinto-Carrasco, E.Rico \& M.M.Mart.Ort., comb. nov. $\equiv$ Phtheirospermum muliense C.Y.Wu \& D.D.Tao in Acta Bot. Yunnan. 18: 307, fig. 4. 1996.

Pterygiella parishii (Hook.f.) Pinto-Carrasco, E.Rico \& M.M.Mart.Ort., comb. nov. $\equiv$ Phtheirospermum parishii Hook.f., Fl. Brit. India 4: 304. 1884.

Pterygiella tenuisecta (Bureau \& Franch.) Pinto-Carrasco, E.Rico \& M.M.Mart.Ort., comb. nov. $\equiv$ Phtheirospermum tenuisectum Bureau \& Franch. in J. Bot. (Morot) 5: 129. 1891.

Relationships within tribe Rhinantheae. - Relationships among genera in tribe Rhinantheae s.str. as presented here are very similar to those previously reported. The position of the

Fig. 5. Majority rule consensus trees from the Bayesian inference analysis, with branch support (PP/BS), showing the K.5- Vernus clade based on A) ITS and B) cpDNA. Other clades belonging to Odontites (K.1- Pyrenaeus, K.2- Macrosyringion, K.3- Bornmuellerantha and K.4- Viscosus) and sister clades (J- Nothobartsia-Odontitella, I- Bellardia) were collapsed. O. = Odontites. Synonyms: O. luteus subsp. lanceolatus $=$ O. lanceolatus subsp. lanceolatus; O. luteus subsp. provincialis $=$ O. lanceolatus subsp. provincialis; O. vernus subsp. fennicus $=$ O. litoralis subsp. fennicus; O. vernus subsp. himalayicus $=$ O. vulgaris subsp. himalayicus; O. vernus subsp. litoralis $=$ O. litoralis subsp. litoralis; O. vernus subsp. serotinus $=O$. vulgaris subsp. vulgaris; O. vernus subsp. siculus $=$ O. vulgaris subsp. siculus. 


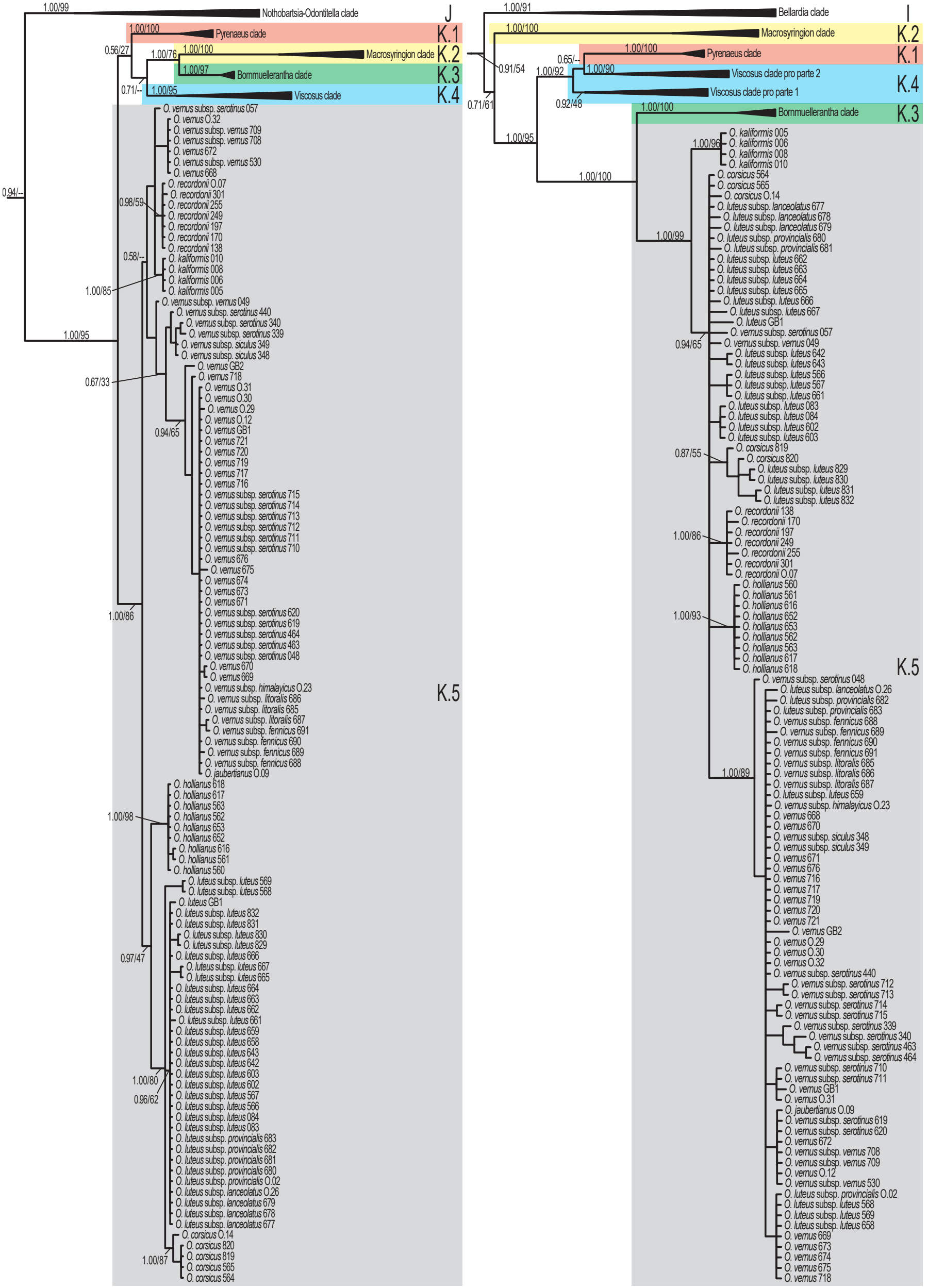


most basal clades (clade C-Melampyrum, clade D-RRL and clade E-Bartsia s.str.) seems to be undisputed, as the same topology was recovered with high support in most studies (Těšitel \& al., 2010; Scheunert \& al., 2012; McNeal \& al., 2013, Uribe-Convers \& Tank, 2015), with only one exception (Gaudeul \& al., 2016), probably due to incorrect outgroup selection. The branching order of the remaining genera is more questionable. The presence of short branches, poorly supported nodes and incongruence among markers results in discordant evolutionary hypotheses among studies. One of the most controversial points is the position of Tozzia. Our study is the first to analyse more than one sample (including T. alpina subsp. carpathica (Woł.) Pawł. \& Jasiewicz $=T$. carpathica Woł.) of Tozzia, confirming its monophyly. With respect to this genus, our topologies disagree with three previously published phylogenies (McNeal \& al., 2013; Uribe-Convers \& Tank 2015;

A

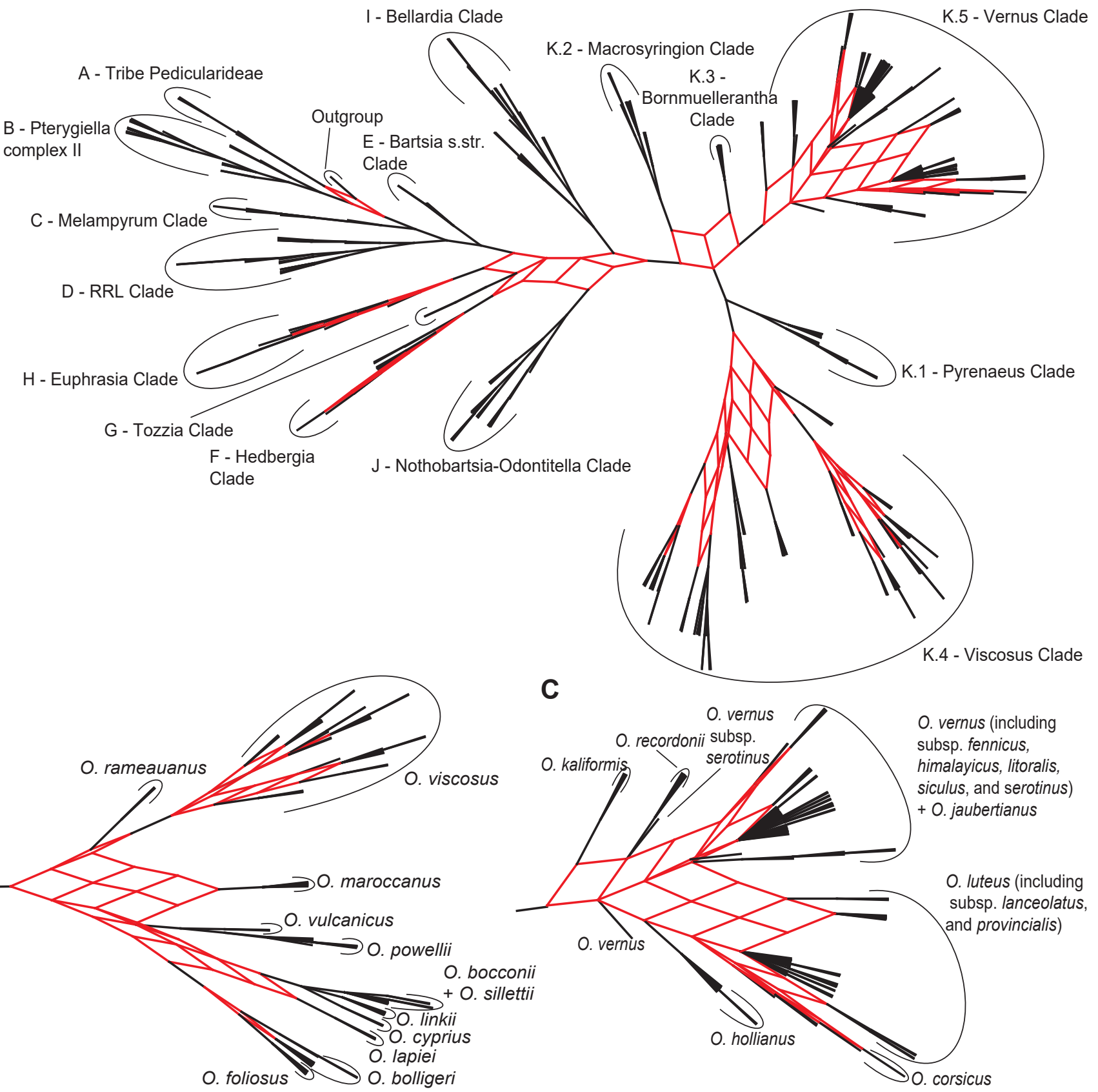

Fig. 6. SuperNetwork obtained from the Bayesian inference trees (branches collapsed at $\mathrm{PP}<0.8$ ) illustrating the incongruence between ITS and cpDNA topologies. Branch lengths were not taken into account. Clades are named as in Figs. 2-4. A, Tribe Rhinantheae; B, K.4-Viscosus clade; C, K.5-Vernus clade. Ma., Macrosyringion; O. = Odontites. Synonyms: O. cyprius =O. linkii subsp. cyprius; O. luteus subsp. lanceolatus $=O$. lanceolatus subsp. lanceolatus; $O$. luteus subsp. provincialis $=O$. lanceolatus subsp. provincialis; O. vernus subsp. fennicus $=O$. litoralis subsp. fennicus; O. vernus subsp. himalayicus $=O$. vulgaris subsp. himalayicus; $O$. vernus subsp. litoralis $=$ O. litoralis subsp. litoralis; $O$. vernus subsp. serotinus $=O$. vulgaris subsp. vulgaris; O. vernus subsp. siculus $=O$. vulgaris subsp. siculus. 
Gaudeul \& al., 2016; Fig. 1), but agree with Scheunert \& al. (2012). In all cases, the phylogenetic relationships of Tozzia are not statistically supported (in both nrDNA and cpDNA trees). Furthermore, the morphology and life form of Tozzia is so different from that of the phylogenetically most closely related genera [e.g., unilocular one-seeded and slightly fleshy indehiscent (sometimes dehiscent by late ripening) fruits vs. bilocular many-seeded dry capsules] that it is not possible to make a suggestion concerning its relationships. The evolutionary history of Tozzia needs more thorough study.

Concerning clade J, our results agree with previous phylogenies (Scheunert \& al., 2012; Gaudeul \& al., 2016) placing the Iberian endemic Odontitella as sister to, however clearly differentiated from, the Iberian subendemic Nothobartsia. Despite the great number of shared character states between Odontitella and Nothobartsia (e.g., strongly bilabiate corolla with entire galea, papillose pubescence of stamen filaments, mucronate anthers, retipilate pollen exine sculpturing, long-stalked calycinal glandular hairs absent; Bolliger \& Molau, 1992), only a few of them differentiate this clade from Odontites (clade K), due to the high morphological variability in the latter genus. Diagnostic characters include the stem indument, which in the members of clade $\mathrm{J}$ is composed only of eglandular antrorse (sometimes antrorse to patent) hairs, while this specific type of hair is never present in Odontites (Benedí, 2009; Rico, 2009). Additionally, corolla colour darkens during anthesis, from yellow to brownish-red, in Odontitella virgata (Link) Rothm. and N. asperrima (Link) Benedí \& Herrero (not observable in N. spicata (Ramond) Bolliger \& Molau as its corolla is invariably purple-violet), while it has never been found to change in any species of Odontites. On the other hand, there are several characters that separate Odontitella and Nothobartsia. Odontitella is an annual, with entire to few-toothed, linear to narrowly lanceolate leaves, bracts resembling the leaves, corolla tube shorter than (or as long as) the calyx, and style clavate beneath the stigma, while Nothobartsia is a perennial, with crenate to dentate, broadly ovate or elliptical leaves, bracts not resembling the leaves, corolla tube longer than calyx, and style not clavate beneath the stigma. The inclusion of Nothobartsia in Odontitella is therefore not supported by morphological data, and phylogenetic data do not provide direct evidence to merge them. Thus, we propose to maintain them as separate genera.

Delimitation and main lineages of Odontites (clade K). The delimitation of Odontites has long been controversial. The topologies presented here generally agree with those of Scheunert $\&$ al. (2012), but disagree with the cpDNA tree obtained by Gaudeul \& al. (2016). In the latter study, Macrosyringion was recovered as sister to a clade composed by Bellardia and Parentucellia, with high support. However, based on our results, and in contrast to the taxonomy used by these authors, we propose that M. longiflorum (Lam.) Rothm. and M. glutinosum (M.Bieb.) Rothm. should be transferred back to Odontites. Consequently, our clade-based definition of Odontites is: the least inclusive crown clade containing $O$. pyrenaeus (Bubani) Rothm., O. longiflorus (Lam.) G.Don., O. aucheri Boiss., O. viscosus (L.) Clairv., and O. vernus (Bellardi) Dumort. (= Euphrasia odontites L.; type of the genus name).
The reinclusion of Macrosyringion in Odontites does not involve any nomenclatural changes, as validly published combinations already exist for these taxa: O. longiflorus (Lam.) G.Don and O. glutinosus (M.Bieb.) Benth. Furthermore, as samples of O. longiflorus subsp. lateritius (Charpin \& Fern. Casas) Sánchez-Gómez and O. longiflorus var. roseus A.Segura did not genetically differ from other samples of $O$. longiflorus, and morphological differences among them are superficial, we do not consider them separate taxonomic entities.

The five main lineages of Odontites can be distinguished morphologically using characters related mainly to the flower and inflorescence (Fig. 2). Table 2 summarizes the states of several morphological traits present in the species of the respective lineages. The morphological characterization of these five lineages is based on the comparison of the extensive descriptions found in the monograph by Bolliger (1996), Flora iberica (Rico, 2009), as well as in the papers where new taxa were described (Dönmez \& Mutlu, 2010; Brullo \& al., 2015). The morphologically most distinct lineages are clade K.2Macrosyringion and clade K.3-Bornmuellerantha, which have at least five and three morphological synapomorphies, respectively; by contrast, the taxa belonging to clade K.4-Viscosus have only one (and a second character state is almost synapomorphic). The K.1-Pyrenaeus and K.5-Vernus lineages share at least nine character states that, despite not being unique, are useful in combination to distinguish these from the remaining lineages. However, in our opinion, the only characters which unambiguously differentiate those two lineages from each other are cell number, orientation of cellular divisions, and outline of the head of the calycinal glandular hairs. In the Lanceolata and Kaliformis-types (present in only some species of the K.5-Vernus clade) of long-stalked glands (Bolliger, 1985), the general arrangement of the glandular head (sphaerical, with two to 16 cells, derived mainly from longitudinal divisions) is almost identical to that of the typical short-stalked glandular hairs differing only in length. In our view, the Lanceolata and Kaliformis-type glands should be reclassified to be included into the variability of the short-stalked glands. Therefore, all members of the K.5-Vernus clade lack long-stalked calycinal glands, while those belonging to the K.1-Pyrenaeus clade show Pyrenaea-type glands (ellipsoid to sphaerical and composed of a much higher number of cells [30-200], which derive from both transversal and longitudinal divisions).

A widely used character, at least in dichotomous keys (e.g., Webb \& Camarasa, 1972; Bolliger, 1996), is corolla colour. However, its usefulness is dubious. Fixed colours are found only in the K.3-Bornmuellerantha and K.1-Pyrenaeus lineages, which consistently have yellow corollas. Nevertheless, there exist species in all other lineages sharing this character state (Fig. 2). Within lineages, corolla colour is useful in K.5-Vernus as stated below. At the species level, corolla colour is almost constant in most cases. In O. longiflorus, O. jaubertianus, and $O$. viscosus, however, this character is polymorphic (yellow and pink in the first two species, and a gradient from yellow to dark red in the latter; Fig. 2). Taking into account these facts, corolla colour can be useful as the main character to differentiate groups of species only in particular cases (e.g., K.5-Vernus clade). 
Although it was not possible to include samples of several narrowly endemic species from North Africa, Sicily, and the Near East in our study, we can place them preliminarily into our lineages, using the cpDNA data from Gaudeul \& al. (2016). Odontites hispidulus (Boiss.) Bolliger, endemic to Lebanon and Syria, is morphologically very similar to O. luteus (L.) Clairv. (Bolliger, 1996). The species was recovered within clade B2 by Gaudeul \& al. (2016), which is part of our K.5Vernus lineage. Based on this evidence, we tentatively consider $O$. hispidulus to be a member of the K.5-Vernus clade. All but one North African species (i.e., O. discolor Pomel, O. purpureus (Desf.) G.Don, O. triboutii Gren. \& Paill. and O. violaceus Pomel), and the Sicilian O. rigidifolius (Biv.) Benth., which were not sampled here, in Gaudeul \& al. (2016) were part of a highly supported clade with $O$. vulcanicus Bolliger, O. powellii Maire, O. linkii Heldr. \& Sart. ex Boiss.,
O. bocconii (Guss.) Walp. and O. lapiei. All of these taxa are found within our K.4-Viscosus lineage; thus, the unsampled species are likely to be part of K.4-Viscosus as well. The only North African species for which phylogenetic affinities remain unknown is the Tunisian endemic $O$. citrinus Bolliger. The morphologically most similar and geographically nearest species is O. triboutii (endemic from NE Algeria and Tunisia), and together they form the Triboutii-group (Bolliger, 1996). Therefore, we tentatively include $O$. citrinus in our K.4Viscosus lineage. A list of taxa included in each lineage is provided in Table 3.

Species monophyly, hybridization, and ILS: Assessing taxonomic boundaries within Odontites. - By including at least two samples per species, we were able to test the monophyly of the vast majority of species studied. Within Odontites, only three species $(O$. alshehbazianus, O. jaubertianus and

Table 2. Morphological characters for differentiation of lineages or groups of species.

\begin{tabular}{|c|c|c|c|c|c|}
\hline & \multicolumn{5}{|c|}{ Lineage } \\
\hline & K.2-Macrosyringion & K.3-Bornmuellerantha & K.4-Viscosus & K.1-Pyrenaeus & K.5-Vernus \\
\hline $\begin{array}{l}\text { Glandular hairs at } \\
\text { base of stem }\end{array}$ & $\begin{array}{l}\text { present } \\
(0.2-0.3 \mathrm{~mm})\end{array}$ & absent & $\begin{array}{l}\text { absent (present - } \\
0.5 \text { to } 3.0 \mathrm{~mm}-\text { in } \\
\left.O . \text { viscosus }^{*}\right)\end{array}$ & \multicolumn{2}{|c|}{ absent } \\
\hline $\begin{array}{l}\text { Long-stalked glands } \\
\text { on calyx }\end{array}$ & $\begin{array}{l}\text { present (longiflora } \\
\text { type) }\end{array}$ & $\begin{array}{l}\text { present (pyrenaea } \\
\text { type) }\end{array}$ & $\begin{array}{l}\text { present (rameauana, } \\
\text { pyrenaea and viscosa } \\
\text { types) or absent }\end{array}$ & $\begin{array}{r}\text { present } \\
\text { (pyrenaea type) }\end{array}$ & absent \\
\hline Corolla shape & strongly bilabiate & subrotate & strongly bilabiate & \multicolumn{2}{|c|}{ strongly bilabiate } \\
\hline Corolla hairs & $\begin{array}{l}\text { glandular plus } \\
\text { eglandular }\end{array}$ & $\begin{array}{l}\text { eglandular (restricted } \\
\text { to lips) }\end{array}$ & $\begin{array}{l}\text { absent or almost } \\
\text { absent (tube with } \\
\text { eglandular hairs in } \\
\text { o. rameauanus) }\end{array}$ & \multicolumn{2}{|c|}{ eglandular } \\
\hline Corolla tube & $\begin{array}{l}\text { long }(2-5 \text { times } \\
\text { longer than calyx) }\end{array}$ & $\begin{array}{l}\text { short (slightly shorter } \\
\text { or longer than calyx) }\end{array}$ & $\begin{array}{l}\text { short (slightly shorter } \\
\text { or longer than calyx) }\end{array}$ & \multicolumn{2}{|c|}{ short (slightly shorter or longer than calyx) } \\
\hline Corolla upper lip & straight & - & folded downwards & straight & $\begin{array}{l}\text { straight or folded } \\
\text { upwards* }\end{array}$ \\
\hline Theca base & mucronate & obtuse & mucronate & \multicolumn{2}{|c|}{ mucronate } \\
\hline Pollen exine & retipilate & retirugulate & $\begin{array}{l}\text { microreticulate or } \\
\text { retipilate }\end{array}$ & \multicolumn{2}{|c|}{ microreticulate } \\
\hline Stigma shape & bilobate & entire & entire & \multicolumn{2}{|c|}{ entire } \\
\hline Habit & annual & annual & annual or perennial* & \multicolumn{2}{|c|}{ annual } \\
\hline Growth form & erect & erect & erect or prostrate & erect & erect or prostrate \\
\hline Inflorescence type & acropetal & acropetal & $\begin{array}{l}\text { acropetal or } \\
\text { basipetal* }\end{array}$ & \multicolumn{2}{|c|}{ acropetal } \\
\hline Toothed bracts & no & no & no & \multicolumn{2}{|c|}{ yes or no } \\
\hline Corolla colour & $\begin{array}{l}\text { yellow or very rarely } \\
\text { pink }\end{array}$ & yellow & $\begin{array}{l}\text { yellow, pink, dark } \\
\text { red* or bicoloured* }\end{array}$ & yellow & yellow or pink \\
\hline $\begin{array}{l}\text { Stamen filament } \\
\text { pubescence }\end{array}$ & papillose & glabrous & papillose or glabrous & papillose & $\begin{array}{l}\text { papillose or pi- } \\
\text { lose* (glabrous in } \\
\text { O. corsicus) }\end{array}$ \\
\hline Seed number & $17-40$ & $10-12$ & $4 *-20$ & $8-14$ & $12-40$ \\
\hline $\begin{array}{l}\text { Chromosome } \\
\text { number }\end{array}$ & $22-24-26$ & 24 & $20-22-24-26$ & 24 & $18 *-20-22-24-26-40 *$ \\
\hline
\end{tabular}

Synapomorphies for each lineage are in bold.

* Character state present in only one lineage, but not shared by all species. 
O. sillettii Brullo \& al.) were represented by a single sequence, and the monophyly of them thus remains undemonstrated. Of the remaining 23 species (78\%), 18 were monophyletic and were recovered as wellsupported clades in at least one dataset (most of them in both datasets). All of them are recognized here as valid species (Table 3). The monophyly of O. linkii (as circumscribed by Bolliger, 1996, i.e., including O. cyprius Boiss. and O. creticus Boiss.) was not supported. In the cpDNA analysis, these sequences formed two clades that corresponded to the samples collected in Cyprus and the Peloponnese, respectively. Additionally, the samples from Cyprus were also recovered as monophyletic in the ITS tree, which encourages us to recognize the taxon as a separate species under the resurrected name $O$. cyprius. The taxonomic status of $O$. creticus remains unknown.

Regarding Odontites hollianus, the samples from Madeira Island (Madeira Archipelago) were molecularly indistinguishable from those collected in La Palma Island (Canary Islands). Morphologically, the Canary Islands plants are very similar to those from Madeira, but there is a slight difference in stamen morphology that has been considered taxonomically useful (i.e., Rothmaler, 1943; Bolliger, 1996). The papillae on the stamen filaments are ca. $45 \mu \mathrm{m}$ long in the Canary Island samples, instead of ca. $30 \mu \mathrm{m}$ in the Madeiran material. Despite their clear isolation by distance (ca. $500 \mathrm{~km}$ ), the incipient morphological differentiation is not sufficient to segregate the Canary Island populations in a new taxon (subspecies or species). Further studies using adequate molecular tools (e.g., microsatellites; Pinto-Carrasco \& al., 2016) are necessary to investigate its genetic isolation and re-evaluate our conservative taxonomic treatment.

By comparing the trees obtained from the ITS and cpDNA datasets, we detected incongruences at three levels (lineages, species, and individuals). The backbones of the ITS and cpDNA trees show short branches and low support (Figs. 3 and 4). This situation is consistent with a scenario where several lineages evolved in a short time (Wortley \& al., 2005). The soft incongruence affecting the K.1-Pyrenaeus and K.4-Viscosus clades could be the result of such a scenario, since each genetic
Table 3. Taxa assigned to particular phylogenetic lineages.

\begin{tabular}{|c|c|}
\hline Lineage & Species and subspecies of Odontites Ludw. \\
\hline \multirow[t]{3}{*}{ K.1-Pyrenaeus } & O. cebennensis H.J.Coste \& Soulié \\
\hline & O. pyrenaeus (Bubani) Rothm. subsp. pyrenaeus \\
\hline & O. pyrenaeus subsp. abilianus P.Monts. \\
\hline \multirow[t]{2}{*}{ K.2-Macrosyringion } & O. glutinosus (M.Bieb.) Benth. \\
\hline & O. longiflorus (Lam.) G.Don \\
\hline \multirow[t]{2}{*}{ K.3-Bornmuellerantha } & O. alshehbazianus (Dönmez \& Mutlu) A.Fleischm. \& Heubl \\
\hline & O. aucheri Boiss. \\
\hline \multirow[t]{24}{*}{ K.4-Viscosus } & O. bocconii (Guss.) Walp. \\
\hline & O. bolligeri E.Rico \& al. \\
\hline & * O. citrinus Bolliger \\
\hline & O. cyprius Boiss. \\
\hline & * O. discolor subsp. ciliatus (Pomel) Bolliger \\
\hline & * O. discolor Pomel subsp. discolor \\
\hline & O. foliosus Peréz Lara \\
\hline & O. lapiei Batt. \\
\hline & O. linkii Heldr. \& Sart. ex Boiss. \\
\hline & O. maroccanus Bolliger \\
\hline & O. powellii Maire \\
\hline & *O. purpureus (Desf.) G.Don \\
\hline & O. rameauanus Emb. \\
\hline & * O. rigidifolius (Biv.) Benth. \\
\hline & O. sillettii Brullo \& al. \\
\hline & * O. triboutii Gren. \& Paill. \\
\hline & *O. violaceus Pomel \\
\hline & O. viscosus subsp. asturicus M.Laínz \\
\hline & O. viscosus subsp. australis (Boiss.) Jahand. \& Maire \\
\hline & O. viscosus subsp. eriopodus Litard. \& Maire \\
\hline & O. viscosus subsp. granatensis (Boiss.) Bolliger \\
\hline & O. viscosus subsp. lusitanicus Bolliger \\
\hline & O. viscosus (L.) Clairv. subsp. viscosus \\
\hline & O. vulcanicus Bolliger \\
\hline \multirow[t]{16}{*}{ K.5-Vernus } & O. corsicus (Loisel.) G.Don. \\
\hline & * O. hispidulus (Boiss.) Bolliger \\
\hline & O. hollianus (Lowe) Benth. \\
\hline & O. jaubertianus (Boreau) D.Dietr. \\
\hline & O. kaliformis (Pourr. ex Willd.) Pau \\
\hline & O. luteus subsp. lanceolatus (Gaudin) P.Fourn. \\
\hline & O. luteus (L.) Clairv. subsp. luteus \\
\hline & O. luteus subsp. provincialis (Bolliger) J.-M.Tison \\
\hline & O. recordonii Burnat \& Barbey \\
\hline & O. vernus subsp. fennicus (Markl.) Pinto-Carrasco \& al. \\
\hline & O. vernus subsp. himalayicus (Pennell) Pinto-Carrasco \& al. \\
\hline & O. vernus subsp. litoralis (Fr.) Nyman \\
\hline & * O. vernus subsp. mesatlanticus (Emb. \& Maire) Pinto-Carrasco \& al. \\
\hline & O. vernus subsp. serotinus Corb. \\
\hline & O. vernus subsp. siculus (Guss.) Sell \\
\hline & O. vernus (Bellardi) Dumort. subsp. vernus \\
\hline
\end{tabular}

* Not included in our molecular analysis. Inclusion in its lineage based on morphological similarity and/or results by Gaudeul \& al. (2016). 
marker could reveal a slightly different evolutionary history. Concerning the phylogenetic relationships among the clades K.3-Bornmuellerantha, K.5-Vernus, and K.2-Macrosyringion observed in the trees, two alternative hypotheses involving ancient homoploid hybridization could be postulated: (A) ancestors of the K.5-Vernus and K.2-Macrosyringion clades hybridized to generate the K.3-Bornmuellerantha clade; or (B) the K.2-Macrosyringion clade was the result of an interspecific cross between the ancestor of the K.3-Bornmuellerantha clade and a currently extinct taxon that would be the ancestor of the extant Odontites. Supporting the first option, species belonging to clades K.5 and K.2 are present where the taxa of K.3 grow today (Near East, from Turkey to the Caspian Sea; Bolliger, 1993, 1996). On the other hand, the low support for the sister relationship of clade K.2 and the remaining clades (K.1, K.3-5) in the cpDNA tree are in agreement with the second hypothesis as this could be the result of not sampling its extinct maternal parent. Morphologically, K.3-Bornmuellerantha and K.2-Macrosyringion are the two most divergent clades (three and five synapomorphies, respectively; Table 2), which blurs their phylogenetic relationships. The choice of either hypothesis would be merely speculative; further studies are needed to clarify this issue. In case reticulate evolutionary processes should have led to the formation of $O$. maroccanus and $O$. bolligeri-O foliosus (and thus would have caused the observed incongruence between nuclear and plastid trees), they might have occurred more recently than those of the Bornmuellerantha/ Macrosyringion clades, as the presumed parents should have been members of the K.4-Viscosus clade. The node ages recently published by Gaudeul \& al. (2016) corroborate our findings. According to these authors, the K.3-Bornmuellerantha clade diverged from the K.5-Vernus clade around 10.3 million years ago (mya), while $O$. maroccanus diverged from $O$. viscosus, and $O$. bolligeri-O foliosus (included under the nomen nudum O. squarrosus; Rico \& al., 2008) from O. lapiei around 4.8 and 2.9 mya, respectively.

Regarding the highly polymorphic $O$. viscosus, not all morphological subspecies constituted molecular clades (Fig. 4). However, the samples were to some extent structured by geography in the ITS tree. This situation might be due to a scenario of recent and/or current gene flow between subspecies in contact zones; this was also postulated using morphological data (gradation in some characters in contact zones; Bolliger, 1996; Rico, 2009). Odontites viscosus subsp. asturicus M.Laínz and O. viscosus subsp. granatensis (Boiss.) Bolliger are morphologically and ecologically similar (small few-branched orophytes), but phylogenetically indistinguishable from $O$. viscosus subsp. australis (Boiss.) Jahand. \& Maire and $O$. viscosus subsp. eriopodus Litard. \& Maire. Finally, the samples of $O$. viscosus subsp. lusitanicus Bolliger group together in both analyses. Despite Rico (2009) considering this subspecies to be part of the huge variability of $O$. viscosus subsp. australis, we temporarily reinstate $O$. viscosus subsp. lusitanicus until further studies shed light on the validity and the distribution range of all subspecies.

The molecular delimitation of the K.5-Vernus clade as a whole was unambiguous (Fig. 5), but species delimitation within this group was more problematic, likely due to extensive phylogenetic incongruence (Fig. 6C). Only four species within the complex were recovered as monophyletic and are therefore accepted here $(O$. corsicus, $O$. hollianus, $O$. kaliformis, and $O$. recordonii). The remaining three species (i.e., Odontites vernus s.1., O. luteus s.l., O. jaubertianus) were completely intermixed in the cpDNA tree. They form two morphological groups of taxa with different corolla colour and floral morphology (O. vernus and O. luteus groups; Bolliger, 1996), with $O$. jaubertianus being morphologically intermediate between them due to its allopolyploid origin (Bolliger \& al., 1990). In the ITS analyses, relationships among taxa were somewhat clearer, and the K.5-Vernus clade was divided into two subclades associated with corolla colour (yellow in $O$. corsicus, O. hollianus, and $O$. luteus s.l., and pink in $O$. kaliformis, $O$. recordonii, $O$. jaubertianus var. jaubertianus, and $O$. vernus s.l.). However, two species recognized by Bolliger (1996), O. litoralis (Fr.) Fr. (with two subspecies), and $O$. vulgaris Moench. (with four subspecies) remain indistinguishable from $O$. vernus, and the same applies to $O$. lanceolatus (Gaudin) Reichenb. (with two subspecies), which cannot be distinguished from O. luteus. That situation could be the result of ILS, and / or recent or current hybridization events. Despite the fact that the already stabilized $O$. jaubertianus is derived from hybridization between O. vernus and O. luteus (Bolliger \& al., 1990), the two latter species are almost completely isolated reproductively. They grow sympatrically in vast areas, but individuals of presumed hybrid origin (intermediate morphology) have very scarcely been reported. No crossing experiments among taxa of the O. luteus complex (i.e., subsp. luteus, subsp. lanceolatus (Gaudin) P. Fourn. and subsp. provincialis (Bolliger) J.-M. Tison) have been made. Nevertheless, there is a morphological gradient between the three subspecies (local adaptation to environmental conditions; Tison \& al., 2010) and interbreeding could be extensive as they grow in partial sympatry and they have the same chromosome number $(2 n=20$, Bolliger, 1996). Taking into account the high genetic and morphological similarity between the taxa formerly called $O$. lanceolatus subsp. lanceolatus and O. lanceolatus subsp. provincialis Bolliger, we consider that the most conservative taxonomic solution is to include them in O. luteus.

Regarding the $O$. vernus complex, the situation is more intricate than in the case of the O. luteus complex, as seven taxa (species and subspecies; Bolliger, 1996), two ploidy levels (di- and tetraploid) and two basic chromosome numbers ( $x$ $=9$ and $x=10$; Delgado \& al., 2015) are involved. The only study of intraspecific hybridization in this group (Snogerup, 1983) was performed using diploids (O. vernus subsp. fennicus (Markl.) Pinto-Carrasco \& al., subsp. litoralis (Fr.) Nyman and subsp. serotinus Corb.; unknown chromosome base number but probably $x=9)$ and tetraploids $(O$. vernus subsp. vernus; $x=10$ ). Diploids are reproductively compatible (within and between subspecies), but almost complete incompatibility occurs between different ploidy levels. Morphologically, the extremes of the variability range are clearly distinguishable, but the wide variation in both vegetative and reproductive characters hampers the attribution to subspecies of a great number 
of individuals (Bolliger, 1996; Rico, 2009). Considering the changes in morphology due to different host plants (Snogerup, 1982), the presence of ecotypes linked to cytotypes (Koutecký $\&$ al., 2012), and the probability of recurrent autopolyploidization (Pinto-Carrasco \& al., in prep.), we recommend cautious taxonomic treatment, i.e., to include $O$. litoralis and $O$. vulgaris (sensu Bolliger, 1996) in O. vernus. In this way, paraphyly could be avoided to some extent as most of the $O$. vernus s.l. samples form one group in the ITS tree. Further studies, using more variable markers, are needed to shed light on the validity of all subspecies that are now included in this complex.

For $O$. litoralis and $O$. vulgaris to be included in the variability of $O$. vernus, the following new combinations are required:

Odontites vernus subsp. fennicus (Markl.) Pinto-Carrasco, E.Rico \& M.M.Mart.Ort., comb. nov. $\equiv$ Odontites litoralis subsp. fennicus Markl. in Acta Soc. Fauna Fl. Fenn. 72(16): 5. 1955 ("fennica").

Odontites vernus subsp. himalayicus (Pennell) Pinto-Carrasco, E.Rico \& M.M.Mart.Ort., comb. nov. $\equiv$ Odontites vulgaris subsp. himalayicus (Pennell) Bolliger in Willdenowia 26: 113. $1996 \equiv$ Odontites himalayicus Pennell, Scroph. W. Himal. (Monogr. Acad. Nat. Sci. Philadelphia 5): 98. 1943.

Odontites vernus subsp. mesatlanticus (Emb. \& Maire) Pinto-Carrasco, E.Rico \& M.M.Mart.Ort., comb. nov. $\equiv$ Odontites vulgaris subsp. mesatlanticus (Emb. \& Maire) Bolliger in Willdenowia 26: 111. $1996 \equiv$ Odontites mesatlanticus Emb. \& Maire in Bull. Soc. Hist. Nat. Afrique N. 22: 58.1931.

\section{ACKNOWLEDGEMENTS}

This research was financed by the Spanish Ministry of Science and Innovation through the projects CGL2011-28613-C03-03 and CGL2012-32574. A predoctoral grant to D.P.C. from the Ministry of Education, Culture and Sport (AP2008-03528) is acknowledged. We are deeply grateful to our laboratory technicians, Tanja Ernst and Teresa Malvar, for their support in the laboratory work, and to all people who helped us during field work, especially to M. Sequeira and A. Acebedo who helped us to collect Odontites hollianus samples. We are also thankful to the curators of all herbaria that sent material on loan. Finally, we are grateful for the constructive comments of the anonymous reviewers that helped to improve the manuscript considerably.

\section{LITERATURE CITED}

Beauverd, G. 1911. Plantes nouvelles ou critiques de la flore du Bassin supérieur du Rhône [New or critical plants from the Flora of the Superior basin of the Rhône river]. Bull. Soc. Bot. Genève, sér. 2, 3: 297-339.

Benedí, C. 2009 Nothobartsia Bolliger \& Molau. Pp. 473-501 in: Benedí, C., Rico, E., Güemes, J. \& Herrero, A. (eds.), Flora iberica, vol. 13, Plantaginaceae-Scrophulariaceae. Madrid: Real Jardín Botánico, CSIC.

Benedí, C., Rico, E., Güemes, J. \& Herrero A. 2009. Scrophulariaceae. Pp. 44-539 in: Benedí, C., Rico, E., Güemes, J. \& Herrero, A. (eds.), Flora iberica, vol. 13, Plantaginaceae-Scrophulariaceae. Madrid: Real Jardín Botánico, CSIC.

Bennett, J.R. \& Mathews, S. 2006. Phylogeny of the parasitic plant family Orobanchaceae inferred from phytochrome A. Amer. J. Bot. 93: 1039-1051. https://doi.org/10.3732/ajb.93.7.1039

Bolliger, M. 1985. Die Drüsenhaare der Gattung Odontites Ludwig (Scrophulariaceae) und ihre systematische Bedeutung [The glandular hairs of the genus Odontites Ludwig (Scrophulariaceae) and their systematic significance]. Bot. Jahrb. Syst. 107: 153-175

Bolliger, M. 1993. Systematik und Chorologie der Gattung Odontites Ludwig s.l. (Scrophulariaceae) [Systematics and chorology of the genus Odontites Ludwig s.l. (Scrophulariaceae)]. Flora, Morphol. Geobot. Ecophysiol. 188: 345-365

Bolliger, M. 1996. Monographie der Gattung Odontites (Scrophulariaceae) sowie der verwandten Gattungen Macrosyringion, Odontitella, Bornmuellerantha und Bartsiella [Monograph of the genus Odontites (Scrophulariaceae) and the related genera Macrosyringion, Odontitella, Bornmuellerantha and Bartsiella]. Willdenowia 26: 37-168. https://doi.org/10.3372/wi.26.2603

Bolliger, M. \& Molau, U. 1992. Nothobartsia, a new genus of Scrophulariaceae from south-west Europe. Pl. Syst. Evol. 179: 59-71. https://doi.org/10.1007/BF00938019

Bolliger, M. \& Wick, L. 1990. The pollen morphology of Odontites (Scrophulariaceae) and its taxonomic significance. Pl. Syst. Evol. 173: 159-178. https://doi.org/10.1007/BF00940860

Bolliger, M., Terrisse, J. \& Heubl, G. 1990. On the allopolyploid origin and the distribution of Odontites jaubertianus (Bor.) D. Dietr. Bot. Jahrb. Syst. 112: 1-27.

Brullo, S., Tomaselli, V. \& Wagensommer, R.P. 2015. A new species of Odontites (Orobanchaceae) from southern Italy. Phytotaxa 213: 271-281. https://doi.org/10.11646/phytotaxa.213.3.7

Darriba, D., Taboada, G.L., Doallo, R. \& Posada, D. 2012. jModelTest 2: More models, new heuristics and parallel computing. Nature, Meth. 9: 772. https://doi.org/10.1038/nmeth.2109

Delgado, L., Pinto-Carrasco, D., Gallego Martín, F. \& Rico, E. 2015. Contribution to the karyological knowledge of Odontites s.l. (Orobanchaceae) on the Iberian Peninsula and in Morocco. Folia Geobot. 50: 63-74. https://doi.org/10.1007/s12224-015-9201-4

Don, G. 1838. A general history of the dichlamydeous plants, vol. 4, Corolliflorae. London: printd for J.G. and F. Rivington, etc. https://doi.org/10.5962/bhl.title.502

Dong, L.-N., Wang, H., Wortley, A.H., Lu, L. \& Li, D.-Z. 2013. Phylogenetic relationships in the Pterygiella complex (Orobanchaceae) inferred from molecular and morphological evidence. Bot. J. Linn. Soc. 171: 491-507. https://doi.org/10.1111/j.1095-8339.2012.01326.x

Dönmez, A.A. \& Mutlu, B. 2010. Bornmuellerantha alshehbaziana (Orobanchaceae), a new species from Turkey. Novon 20: 265-267. https://doi.org/10.3417/2008110

Doyle, J.J. \& Doyle, J.L. 1987. A rapid DNA isolation procedure for small quantities of fresh leaf tissue. Phytochem. Bull. Bot. Soc. Amer. 19: 11-15.

Gaudeul, M., Véla, E. \& Rouhan, G. 2016. Eastward colonization of the Mediterranean Basin by two geographically structured clades: The case of Odontites Ludw. (Orobanchaceae). Molec. Phylogen. Evol. 96: 140-149. https://doi.org/10.1016/j.ympev.2015.12.008

Goloboff, P.A., Farris, J.S. \& Nixon, K.C. 2008. TNT, a free program for phylogenetic analysis. Cladistics 24: 774-786. https://doi.org/10.1111/j.1096-0031.2008.00217.x

Gussarova, G., Popp, M., Vitek, E. \& Brochmann, C. 2008. Molecular phylogeny and biogeography of the bipolar Euphrasia (Orobanchaceae): Recent radiations in an old genus. Molec. Phylogen. Evol. 48: 444-460. https://doi.org/10.1016/j.ympev.2008.05.002 
Hills, D.M. \& Bull, J.J. 1993. An empirical test of bootstrapping as a method for assessing confidence in phylogenetic analysis. Syst. Biol. 42: 182-192. https://doi.org/10.1093/sysbio/42.2.182

Hong, D.Y., Yang, H., Jin, C. \& Holmgren, N.H. 1998. Scrophulariaceae. Pp. 1-212 in: Wu, Z.Y. \& Raven, P.H. (eds.), Flora of China, vol. 18. Beijing: Science Press; St. Louis: Missouri Botanical Garden Press.

Huelsenbeck, J.P. \& Rannala, B. 2004. Frequentist properties of bayesian posterior probabilities of phylogenetic trees under simple and complex substitution models. Syst. Biol. 53: 904-913. https://doi.org/10.1080/10635150490522629

Huson, D.H. \& Bryant D. 2006. Application of phylogenetic networks in evolutionary studies. Molec. Biol. Evol. 23: 254-267. https://doi.org/10.1093/molbev/msj030

İnceoğlu, Ö. 1982. Pollen grains in some Turkish Rhinantheae (Scrophulariaceae). Grana 21: 83-96. https://doi.org/10.1080/00173138209427684

Kearse, M., Moir, R., Wilson, A., Stones-Havas, S., Cheung, M., Sturrock, S., Buxton, S., Cooper, A., Markowitz, S., Duran, C., Thierer, T., Ashton, B., Mentjies, P. \& Drummond, A. 2012. Geneious Basic: An integrated and extendable desktop software platform for the organization and analysis of sequence data. Bioinformatics 28: 1647-1649. https://doi.org/10.1093/bioinformatics/bts199

Kerner, A. 1888. Ueber die Bestäubungseinrichtungen der Euphrasieen [About the pollination features of Euphrasia]. Verh. Zool.-Bot. Ges. Wien 38: 563-566.

Koutecký, P., Tuleu, G., Bad'urová, T., Košnar, J., Štech, M. \& Těšitel, J. 2012. Distribution of cytotypes and seasonal variation in the Odontites vernus group in central Europe. Preslia 84: 887-904.

Kubatko, L.S. 2009. Identifying hybridization events in the presence of coalescence via model selection. Syst. Biol. 58: 478-88. https://doi.org/10.1093/sysbio/syp055

Linnaeus, C. 1753. Species plantarum, 2. vols. Holmiae [Stockholm]: impensis Laurentii Salvii. https://doi.org/10.5962/bhl.title.669

Lu, L., Wang, H., Blackmore, S., Li, D.Z., \& Dong, L.-N. 2007. Pollen morphology of the tribe Rhinantheae (Orobanchaceae) and its systematic significances. Pl. Syst. Evol. 268: 177-198. https://doi.org/10.1007/s00606-007-0562-x

Maddison, W.P. \& Maddison, D.R. 2014. Mesquite: A modular system for evolutionary analysis, version 3.01. http://mesquiteproject.org/

McNeal, J.R., Bennett, J.R., Wolfe, A.D. \& Mathews, S. 2013. Phylogeny and origins of holoparasitism in Orobanchaceae. Amer. J. Bot. 100: 971-983. https://doi.org/10.3732/ajb.1200448

Minkin, J.P. \& Eshbaugh, W.H. 1989. Pollen morphology of the Orobanchaceae and rhinanthoid Scrophulariaceae. Grana 28: 1-18. https://doi.org/10.1080/00173138909431007

Molau, U. 1988. Hedbergia, a new genus of Scropbulariaceae from Africa. Nordic J. Bot. 8: 193-195. https://doi.org/10.1111/j.1756-1051.1988.tb00500.x

Molau, U. 1990. The genus Bartsia (Scrophulariaceae-Rhinanthoideae). Opera Bot. 102: 1-99.

Müller, K.F. 2005. SeqState: Primer design and sequence statistics for phylogenetic DNA datasets. Appl. Bioinf. 4: 65-69. https://doi.org/10.2165/00822942-200504010-00008

Pinto-Carrasco, D., Košnar, J., López-González, N., Koutecký, P., Těšitel, J., Rico, E. \& Martínez-Ortega, M.M. 2016. Development of 14 microsatellite markers in Odontites vernus s.l. (Orobanchaceae) and cross-amplification in related taxa. Appl. Pl. Sci. 4: 1500111. https://doi.org/10.3732/apps.1500111

Rambaut, A., Suchard, M.A., Xie, D. \& Drummond, A.J. 2015. Tracer, version 1.6. http://beast.bio.ed.ac.uk/Tracer

Rico, E. 2009. Odontites Ludw.; Odontitella Rothm.; Macrosyringion Rothm. Pp. 473-501 in: Benedí, C., Rico, E., Güemes, J. \& Herrero, A. (eds.), Flora iberica, vol. 13, Plantaginaceae-Scrophulariaceae. Madrid: Real Jardín Botánico, CSIC.
Rico, E., Delgado, L. \& Herrero, A. 2008. Reassessing the Odontites purpureus group (Orobanchaceae) from south-east Spain and north-west Africa. Bot. J. Linn. Soc. 158: 701-708. https://doi.org/10.1111/j.1095-8339.2008.00892.x

Ronquist, F., Huelsenbeck, J.P. \& Van der Mark, P. 2009. Bayesian phylogenetic analysis using MrBayes. Pp. 210-265 in: Lemey, P., Salemi, M. \& Vandamme, A. (eds.), The phylogenetic handbook: A practical approach to phylogenetic analysis and hypothesis testing, ed. 2. Cambridge: Cambridge University Press. https://doi.org/10.1017/CBO9780511819049.009

Ronquist, F., Teslenko, M., Van der Mark, P., Ayres, D.L., Darling, A., Höhna, S., Larget, B., Liu, L., Suchard, M.A. \& Huelsenbeck, J.P. 2012. MrBayes 3.2: Efficient Bayesian phylogenetic inference and model choice across a large model space. Syst. Biol. 61: 539-542. https://doi.org/10.1093/sysbio/sys029

Rothmaler, W. 1943. Die Aufspaltung von Odontites Hall. ex Zinn. [The splitting of Odontites Hall. ex Zinn.]. Mitth. Thüring. Bot. Vereins 50: 224-230.

Scheunert, A., Fleischmann, A., Olano-Marín, C., Bräuchler, C. \& Heubl, G. 2012. Phylogeny of tribe Rhinantheae (Orobanchaceae) with a focus on biogeography, cytology and re-examination of generic concepts. Taxon 61: 1269-1285.

Simmons, M.P. \& Ochoterena, H. 2000. Gaps as characters in sequence-based phylogenetic analyses. Syst. Biol. 49: 369-381. https://doi.org/10.1093/sysbio/49.2.369

Snogerup, B. 1982. Host influence on northwest European taxa of Odontites (Scrophulariaceae). Ann. Bot. Fenn. 19: 17-30.

Snogerup, B. 1983. Northwest European taxa of Odontites (Scrophulariaceae). Acta Bot. Fenn. 124: 1-62.

Soltis, D.E. \& Soltis, P.S. 1993. Molecular data and the dynamic nature of polyploidy. Crit. Rev. Pl. Sci. 12: 243-273. https://doi.org/10.1080/07352689309701903

Soltis, D.E. \& Soltis, P.S. 1999. Polyploidy: Recurrent formation and genome evolution. Trends Ecol. Evol. 14: 348-352. https://doi.org/10.1016/S0169-5347(99)01638-9

Swofford, D.L. 2002. PAUP*: Phylogenetic analysis using parsimony (*and other methods). Sunderland, Massachusetts: Sinauer.

Ter Borg, S.J. 1985. Population biology and habitat relations of some hemiparasitic Scrophulariaceae. Pp. 463-487 in: White J. (ed.), The population structure of vegetation. Dordrecht: Junk. https://doi.org/10.1007/978-94-009-5500-4_19

Těšitel, J., Říha, P., Svobodová, Š., Malinová, T. \& Štech, M. 2010. Phylogeny, life history evolution and biogeography of the Rhinanthoid Orobanchaceae. Folia Geobot. 45: 347-367. https://doi.org/10.1007/s12224-010-9089-y

Tison, J.M., Jauzein, P., Girod, C. \& Espeut, M. 2010. Combinaisons et statuts nouveaux proposés dans la "Flore de la France Méditerranéenne continentale" [New combinations and status proposed in "Flore de la France Méditerranéenne continentale"]. Biocosme Mésogéen 27: 109-133

Uribe-Convers, S. \& Tank, D.C. 2015. Shifts in diversification rates linked to biogeographic movement into new areas: An example of a recent radiation in the Andes. Amer. J. Bot. 102: 1854-1869. https://doi.org/10.3732/ajb.1500229

Uribe-Convers, S., Settles, M.L. \& Tank, D.C. 2016. A phylogenomic approach based on PCR target enrichment and high throughput sequencing: Resolving the diversity within the South American species of Bartsia L. (Orobanchaceae). PLoS ONE 11: e0148203. https://doi.org/10.1371/journal.pone.0148203

Webb, D.A. \& Camarasa, J.M. 1972. Odontites Ludwig. Pp. 266-269 in: Tutin, T.G., Heywood, V.H., Burges, N.A., Moore, D.M., Valentine, D.H., Walters, S.M. \& Webb, D.A (eds.), Flora Europaea, vol. 3. Cambridge: Cambridge University Press.

Wolfe, A.D., Randle, C.P., Liu, L. \& Steiner, K.E. 2005. Phylogeny and biogeography of Orobanchaceae. Folia Geobot. 40: 115-134. https://doi.org/10.1007/BF02803229

Wortley, A.H., Rudall, P.J., Harris, D.J. \& Scotland, R.W. 2005. 
How much data are needed to resolve a difficult phylogeny? Case study in Lamiales. Syst. Biol. 54: 697-709. https://doi.org/10.1080/10635150500221028

Young, N.D., Steiner, K.E. \& dePamphilis, C.W. 1999. The evolution of parasitism in Scrophulariaceae/Orobanchaceae: Plastid gene sequences refute an evolutionary transition series. Ann. Missouri Bot. Gard. 86: 876-893. https://doi.org/10.2307/2666173

Zhou, Q.-M., Jensen, S.R., Liu, G.-L., Wang, S. \& Li, H.-Q. 2014. Familial placement of Wightia (Lamiales). Pl. Syst. Evol. 300: 2009-2017. https://doi.org/10.1007/s00606-014-1029-5

Appendix 1. Details of sequences (1) newly generated in this study and (2) obtained from GenBank. For newly generated data, we give information about taxon, ID, DNA source, locality, longitude, latitude, collectors, collection number (and/or exsiccatae number), herbarium voucher, and NCBI accession numbers. For sequences obtained from GenBank, we give taxon, ID, NCBI accession numbers and references where they were originally published (see end of Appendix). In both cases accession numbers are shown in the following order: ITS, trnK and rpsl6. Unavailable sequences are indicated by a dash (-). The taxon names previous to the taxonomic changes proposed in this paper are shown in brackets. DNA source was silica gel-dried material (s) and herbarium specimens (h). * Coordinates assignment based on locality description; ** silica gel-dried material and voucher specimens were collected in the same location but on different dates.

\section{(1) Sequences produced for this study}

Bellardia trixago (L.) All., 629, s, Spain, Cáceres, Poblado del embalse de Gabriel y Galán, -6.12514, 40.22047, M. Martínez Ortega \& X. Giráldez Fernández, MO 6020 (SALA 142078), KX958618, KX959115, KX958866; Bellardia trixago, 630, s, Spain, Cáceres, Poblado del embalse de Gabriel y Galán, -6.12514, 40.22047, M. Martínez Ortega \& X. Giráldez Fernández, MO 6020 (SALA 142078), KX958619, KX959116, KX958867; Bellardia trixago, 698, s, Spain, Burgos, Castrillo de la Vega, -3.78344, 41.65452, D. Pinto Carrasco, DP 918 (SALA 142076), KX958685, KX959182, KX958933; Bellardia trixago, 699, s, Spain, Burgos, Castrillo de la Vega, -3.78344, 41.65452, D. Pinto Carrasco, DP 918 (SALA 142076), KX958686, KX959183, KX958934; Bellardia viscosa (L.) Fisch. \& C.A.Mey., 633, s, Spain, Cáceres, between Guijo de Granadilla and Mohedas de Granadilla, -6.18073, 40.22402, M. Martínez Ortega \& X. Giráldez Fernández, MO 6021 (SALA 142079), KX958622, KX959119, KX958870; Bellardia viscosa, 634, s, Spain, Cáceres, between Guijo de Granadilla and Mohedas de Granadilla, -6.18073, 40.22402, M. Martínez Ortega \& X. Giráldez Fernández, MO 6021 (SALA 142079), KX958623, KX959120, KX958871; Euphrasia hirtella Jord. ex Reut., 702, s, Spain, Ávila, San Martín de la Vega del Alberche, -5.150, 40.431, E. Rico \& V. Lucía, ER 8041 (SALA 142118), KX958689, KX959186, KX958937; Euphrasia hirtella, 703, s, Spain, Ávila, San Martín de la Vega del Alberche, -5.150, 40.431, E. Rico \& V. Lucía, ER 8041 (SALA 142118), KX958690, KX959187, KX958938; Nothobartsia asperrima (Link) Benedí \& Herrero, 615, s, Portugal, Setúbal, Sesimbra, Cabo Espichel, -9.2108, 38.4142, M. Santos Vicente \& al., MS 960 (SALA 123311), KX958604, KX959101, KX958852; Nothobartsia asperrima, 637, s, Portugal, Santarem, Tomar, Algarvias, -8.431, 39.594, E. Rico, ER 7909 (SALA 123313), KX958626, KX959123, KX958874; Nothobartsia asperrima, 638, s, Portugal, Santarem, Tomar, Algarvias, -8.431, 39.594, E. Rico, ER 7909 (SALA 123313), KX958627, KX959124, KX958875; Nothobartsia asperrima, 639, s, Portugal, Setúbal, Sesimbra, Cabo Espichel, -9.2108, 38.4142, M. Santos Vicente \& al., MS 960 (SALA 123311), KX958628, KX959125, KX958876; Nothobartsia asperrima, 640, s, Portugal, Setúbal, Vendas de Azeitão, -8.9843, 38.5284, M. Santos Vicente \& al., MS 958 (SALA 123310), KX958629, KX959126, KX958877; Nothobartsia asperrima, 641, s, Portugal, Setúbal, Vendas de Azeitão, -8.9843, 38.5284, M. Santos Vicente \& al., MS 958 (SALA 123310), KX958630, KX959127, KX958878; Nothobartsia asperrima, 821, s, Morocco, Tanger-Tétouan, between Sidi Jel and Beni Bouker, -5.12731, 35.18902, D. Pinto Carrasco \& al., DP 1062 (SALA 156176), KX958708, KX959205, KX958956; Nothobartsia asperrima, 822, s, Morocco, Tanger-Tétouan, between Sidi Jel and Beni Bouker, -5.12731, 35.18902, D. Pinto Carrasco \& al., DP 1062 (SALA 156176), KX958709, KX959206, KX958957; Nothobartsia spicata (Ramond) Bolliger \& Molau, 613, s, Spain, Santander, Peñarrubia, La Hermida, -4.64, 43.26, E. Rico, ER 7921 (SALA 125801), KX958602, KX959099, KX958850; Nothobartsia spicata, 614, s, Spain, Santander, Peñarrubia, La Hermida, -4.64, 43.26, E. Rico, ER 7921 (SALA 125801), KX958603, KX959100, KX958851; Nothobartsia spicata, 635, s, Spain, Oviedo, Ribadesella, -5.03, 43.43, E. Rico, ER 7920 (SALA 125802), KX958624, KX959121, KX958872; Nothobartsia spicata, 636, s, Spain, Oviedo, Ribadesella, -5.03, 43.43, E. Rico, ER 7920 (SALA 125802), KX958625, KX959122, KX958873; Odontitella virgata (Link) Rothm., 81, s, Spain, Burgos, Castrillo de la Vega, -3.75889, 41.64505, D. Pinto Carrasco, DP 14 (SALA 135636), KX958509, KX959006, KX958757; Odontitella virgata, 592, s, Spain, Cádiz, Los Barrios, -5.59, 36.22, E. Rico, ER 7959 (SALA 136278), KX958581, KX959078, KX958829; Odontitella virgata, 593, s, Spain, Cádiz, Los Barrios, -5.59, 36.22, E. Rico, ER 7959 (SALA 136278), KX958582, KX959079, KX958830; Odontitella virgata, 594, s, Spain, A Coruña, Santiso, Barazón, -8.00755, 42.85990, L. Delgado Sánchez \& al., LD 1069 (SALA 136280), KX958583, KX959080, KX958831; Odontitella virgata, 595, s, Spain, A Coruña, Santiso, Barazón, -8.00755, 42.85990, L. Delgado Sánchez \& al., LD 1069 (SALA 136280), KX958584, KX959081, KX958832; Odontites aucheri Boiss., 644, h, Turkey, Erzincan, Sakaltutan Geçidi, 39.12, 39.87, J. Aldasoro \& al., A-2691 (SALA 120807), KX958633, KX959130, KX958881; Odontites aucheri, 645, h, Turkey, Sivas, Dogançal, 38.03, 39.88, J. Aldasoro \& al., A-2783 (SALA 121447), KX958634, KX959131, KX958882; Odontites aucheri, 646, h, Armenia, Ararat, Lusashogh, 44.9653, 39.8597, M. Oganesian \& al., 03-1575 (MA 742689), KX958635, KX959132, KX958883; Odontites aucheri, O.24, h, Armenia, Ararat, Lusashogh, 44.9653, 39.8597, M. Oganesian \& al., 03-1575 (MSB 123864), KX958740, KX959237, KX958988; Odontites bocconii (Guss.) Walp., 624, s, Italy, Sicily, San Martino delle Scale, 13.2581, 38.0861, G. Domina, s.n. (PAL 90581), KX958613, KX959110, KX958861; Odontites bocconii, 625, s, Italy, Sicily, San Martino delle Scale, 13.2581, 38.0861, G. Domina, s.n. (PAL 90581), KX958614, KX959111, KX958862; Odontites bocconii, 694, h, Italy, Sicily, Chiusa Sclafani, 13.28698, 37.66516, G. Certa, Soc. Éch. Pl. Vasc. Eur. Occid. Médit. nr. 18421 (SALA 118685), KX958681, KX959178, KX958929; Odontites bocconii, 823, s, Italy, Sicily, Le Madonie National Park, near Monte Scalone, 14.02147, 37.84662, J. Peñas de Giles \& al., JPG-11-03 (SALA 142125), KX958710, KX959207, KX958958; Odontites bocconii, 824, s, Italy, Sicily, Le Madonie National Park, near Monte Scalone, 14.02147, 37.84662, J. Peñas de Giles \& al., JPG-11-03 (SALA 142125), KX958711, KX959208, KX958959; Odontites bocconii, O.13, h, Italy, Sicily, Chiusa Sclafani, 13.28698, 37.66516, G. Certa, Soc. Éch. Pl. Vasc. Eur. Occid. Médit. nr. 18421 (M), KX958730, KX959227, KX958978; Odontites bocconii, O.20, h, Italy, Sicily, 9 km N of Polizzi Generosa, 14.01, 37.84, J.R. Akeroyd \& al., 3664 (B 10 0050066), KX958736, KX959233, KX958984; Odontites bolligeri E.Rico, L.Delgado \& Herrero, 89, s, Spain, Granada, Restábal, -3.57582, 36.92045, M. Martinez Ortega \& al., MO 4566 (SALA 135619), KX958517, KX959014, KX958765; Odontites bolligeri, 90, s, Spain, Granada, Restábal, -3.57582, 36.92045, M. Martínez Ortega \& al., MO 4566 (SALA 135619), KX958518, KX959015, KX958766; Odontites bolligeri, 574, s, Morocco, Oriental, Béni Snassen Natural Park, -2.37950, 34.80917, A. Quintanar \& al., AQ 2812 (SALA 142142), KX958563, KX959060, KX958811; Odontites bolligeri, 575, s, Morocco, Oriental, Béni Snassen Natural Park, -2.37950, 34.80917, A. Quintanar \& al., AQ 2812 (SALA 142142), KX958564, KX959061, KX958812; Odontites bolligeri, 609, s, Spain, Málaga, Frigiliana, -3.89672, 36.77680, D. Pinto Carrasco \& V. Lucía, DP 832 (SALA 136804), KX958598, KX959095, KX958846; Odontites bolligeri, 610, s, Spain, Málaga, Frigiliana, -3.89672, 36.77680, D. Pinto Carrasco \& V. Lucía, DP 832 (SALA 136804), KX958599, KX959096, KX958847; Odontites bolligeri, O.17, h, Spain, Almeria, Laujar de Andarax, -2.87629, 37.00067, L. Posadas \& al., s.n. (MA 861304), KX958733, KX959230, KX958981; Odontites bolligeri, O.18, h, Morocco, Oriental, Béni Snassen Natural Park, -2.37500, 34.81983, A. Quintanar \& al., AQ 2816 (MA 782726), KX958734, KX959231, KX958982; Odontites bolligeri, O.19, h, Morocco, Oriental, Béni Snassen Natural Park, -2.37950, 34.80917, A. Quintanar \& al., AQ 2812 (MA 782731), KX958735, KX959232, KX958983; Odontites bolligeri, O.27, h, Spain, Granada, Orjiva, Sierra de Lújar, -3.4, 36.9*, H. Merxmüller \& W. Gleißner, 29171 (M), KX958743, KX959240, KX958991; Odontites cebennensis H.J.Coste \& Soulié, 87, s, Spain, Barcelona, La Pobla de Lillet, 2.01349, 42.24492, D. Pinto Carrasco \& al., DP 628 (SALA 135679), KX958515, KX959012, KX958763; Odontites cebennensis, 88, s, Spain, Barcelona, La Pobla de Lillet, 2.01349, 42.24492, D. Pinto Carrasco \& al., DP 628 (SALA 135679), KX958516, KX959013, KX958764; Odontites cebennensis, 607, s, Spain, Barcelona, Cercs, 1.86497, 42.14434, D. Pinto Carrasco \& al., DP 632 (SALA 135683), KX958596, KX959093, KX958844; Odontites cebennensis, 608, s, Spain, Barcelona, Cercs, 1.86497, 42.14434, D. Pinto Carrasco \& al., DP 632 (SALA 135683), KX958597, KX959094, KX958845; 
Appendix 1. Continued.

Odontites cebennensis, O.03, h, Spain, Barcelona, between Sant Quirze de Besora and Ripoll, 2.2, 42.1*, M. Bolliger, 0-23 (M), KX958722, KX959219, KX958970; Odontites cebennensis, O.06, h, Spain, Gerona, between Campdevanol and La Pobla de Lillet, 2.1, 42.2*, M. Bolliger, 0-45 (M), KX958724, KX959221, KX958972; Odontites cebennensis, O.25, h, Spain, Gerona, Ripoll, 2.2, 42.2*, F. Sennen, s.n. (M), KX958741, KX959238, KX958989; Odontites corsicus (Loisel.) G.Don., 564, s, France, Corsica, Olmeta-di-Capocorso, Bocca di San Ghjacintu, 9.3842, 42.7489, A. Tribsch, s.n. (SALA 137639), KX958553, KX959050, KX958801; Odontites corsicus, 565, s, France, Corsica, Olmeta-di-Capocorso, Bocca di San Ghjacintu, 9.3842, 42.7489, A. Tribsch, s.n. (SALA 137639), KX958554, KX959051, KX958802; Odontites corsicus, 819, s, France, Corsica, Olmeta-di-Capocorso, Bocca di San Ghjacintu, 9.3842, 42.7489, A. Tribsch, s.n. (SALA 137639), KX958706, KX959203, KX958954; Odontites corsicus, 820, s, France, Corsica, Olmeta-di-Capocorso, Bocca di San Ghjacintu, 9.3842, 42.7489, A. Tribsch, s.n. (SALA 137639), KX958707, KX959204, KX958955; Odontites corsicus, O.14, h, France, Corsica, Col de Vergio, 8.9, 42.3*, J. Lambinon, 98/765 Soc. Éch. Pl. Vasc. Eur. Occid. Médit. nr. 19537 (M), KX958731, KX959228, KX958979; Odontites cyprius Boiss. [Odontites linkii subsp. cyprius (Boiss.) Bolliger], 695, h, Cyprus, Larnaka, Páno Léfkara, 33.3, 34.9*, Alziar \& al., Iter Med. IV nr. 0762 (MA 495442), KX958682, KX959179, KX958930; Odontites cyprius [Odontites linkii subsp. cyprius], O.22, h, Cyprus, Kirenia, Saint Hilarion, 33.2547, 35.3078, E. Vitek, 04-1961 (M), KX958738, KX959235, KX958986; Odontites foliosus Peréz Lara, 91, s, Spain, Cádiz, Puerto Real, -6.14, 36.51, E. Rico \& al., ER 7939 (SALA 134536), KX958519, KX959016, KX958767; Odontites foliosus, 92, s, Spain, Cádiz, Puerto Real, -6.14, 36.51, E. Rico \& al., ER 7939 (SALA 134536), KX958520, KX959017, KX958768; Odontites foliosus, 611, s, Spain, Málaga, Manilva, -5.26139, 36.34094, D. Pinto Carrasco \& al., DP 821 (SALA 156297), KX958600, KX959097, KX958848; Odontites foliosus, 612, s, Spain, Málaga, Manilva, -5.26139, 36.34094, D. Pinto Carrasco \& al., DP 821 (SALA 156297), KX958601, KX959098, KX958849; Odontites foliosus, 626, s, Spain, Cádiz, Barbate, Los Caños de Meca, -5.958, 36.182, E. Rico, ER 7903 (**SALA 103775), KX958615, KX959112, KX958863; Odontites glutinosus (M.Bieb.) Benth. [Macrosyringion glutinosum (M.Bieb.) Rothm.], 650, h, Bulgaria, Pernik, Golo Bŭrdo, 23.1, 42.6*, H. Kocev \& N. Vihodcevsky, Pl. Bu. Ex., Cent. VI nr.586 (MA 183144), KX958639, KX959136, KX958887; Odontites glutinosus [Macrosyringion glutinosum], 651, h, Turkey, Erzincan, Sakaltutan Geçidi, 39.12, 39.87, J. Aldasoro \& al., A-2687 (MA 689821), KX958640, KX959137, KX958888; Odontites hollianus (Lowe) Benth., 560, s, Portugal, Madeira, between O Ninho da Manta and O Pico Cidrão, -16.94415, 32.74116, M. Sequeira \& al., MS 5056 (SALA 125030), KX958549, KX959046, KX958797; Odontites hollianus, 561, s, Portugal, Madeira, between O Ninho da Manta and O Pico Cidrão, -16.94415, 32.74116, M. Sequeira \& al., MS 5056 (SALA 125030), KX958550, KX959047, KX958798; Odontites hollianus, 562, s, Spain, Isla de La Palma, Tijarafe, -17.92329, 28.73860, M. Díaz \& al., PALMA 240610 (SALA 156496), KX958551, KX959048, KX958799; Odontites hollianus, 563, s, Spain, Isla de La Palma, Tijarafe, -17.92329, 28.73860, M. Díaz \& al., PALMA 240610 (SALA 156496), KX958552, KX959049, KX958800; Odontites hollianus, 616, s, Portugal, Madeira, between Pico do Arieiro and Pico Ruivo, -16.94, 32.73, S. Castroviejo \& al., SC 17379 (MA 714540), KX958605, KX959102, KX958853; Odontites hollianus, 617, s, Spain, Isla de La Palma, Tijarafe, -17.92329, 28.73860, M. Díaz \& al., PALMA 240610 (SALA 156496), KX958606, KX959103, KX958854; Odontites hollianus, 618, s, Spain, Isla de La Palma, Tijarafe, -17.92329, 28.73860, M. Díaz \& al., PALMA 240610 (SALA 156496), KX958607, KX959104, KX958855; Odontites hollianus, 652, h, Portugal, Madeira, Encumeada, -17.0, 32.8*, M. Velayos, 9717 (MA 655312), KX958641, KX959138, KX958889; Odontites hollianus, 653, h, Portugal, Madeira, between Ribeiro Frio and Os Balcoes, -16.9, 32.7*, J. Malato Beliz, 1698 (MA 303197), KX958642, KX959139, KX958890; Odontites jaubertianus (Boreau) D.Dietr., O.09, h, France, Charente, Saint-Angeau, 0.3, 45.8*, A. Terrisse, 0-151 (M), KX958726, KX959223, KX958974; Odontites kaliformis (Pourr. ex Willd.) Pau, 5, s, Spain, Valencia, Sagunto, -0.25, 39.63, E. Rico \& al., ER 7913 (SALA 124706), KX958502, KX958999, KX958750; Odontites kaliformis, 6, s, Spain, Valencia, Sagunto, -0.25, 39.63, E. Rico \& al., ER 7913 (SALA 124706), KX958503, KX959000, KX958751; Odontites kaliformis, 8, s, Spain, Castellón, Cabanes, 0.18, 40.18, E. Rico \& al., ER 7914 (SALA 124707), KX958504, KX959001, KX958752; Odontites kaliformis, 10, s, Spain, Castellón, Cabanes, 0.18, 40.18, E. Rico \& al., ER 7914 (SALA 124707), KX958505, KX959002, KX958753; Odontites lapiei Batt., 696, h, Algeria, Tizi Ouzou, Djurdjura National Park, Djebel Heïdzer, 4.0, 36.5*, A. Dubuis \& al., Soc. Éch. Pl. Vasc. Eur. Occid. Médit. nr. 18423 (SALA 118683), KX958683, KX959180, KX958931; Odontites lapiei, 697, h, Algeria, Tizi Ouzou, Djurdjura National Park, Djebel Heïdzer, 4.0, 36.5*, A. Dubuis \& al., Soc. Éch. Pl. Vasc. Eur. Occid. Médit. nr. 18423 (SALA 118683), KX958684, KX959181, KX958932; Odontites lapiei, O.10, h, Algeria, Tizi Ouzou, Djurdjura National Park, Djebel Heïdzer, 4.0, 36.5*, A. Dubuis \& al., Soc. Éch. Pl. Vasc. Eur. Occid. Médit. nr. 18423 (MSB), KX958727, KX959224, KX958975; Odontites linkii Heldr. \& Sart. ex Boiss., 570, s, Greece, Corinthia, Trikala, 22.4639, 37.9832, A. Herrero \& al., AH 3480 (SALA 140486), KX958559, KX959056, KX958807; Odontites linkii, 571, s, Greece, Corinthia, Trikala, 22.4639, 37.9832, A. Herrero \& al., AH 3480 (SALA 140486), KX958560, KX959057, KX958808; Odontites linkii, 621, s, Greece, Achaea, between Kalávrita and Kalivitis, 22.1708, 38.0807, A. Herrero \& al., AH 3359 (SALA 140386), KX958610, KX959107, KX958858; Odontites linkii, 622, s, Greece, Lakonia, Lagadha gorge, 22.3355, 37.0940, C. Aedo, CA 14257 (SALA 140800), KX958611, KX959108, KX958859; Odontites linkii, 623, s, Greece, Lakonia, Lagadha gorge, 22.3355, 37.0940, C. Aedo, CA 14257 (SALA 140800), KX958612, KX959109, KX958860; Odontites longiflorus (Lam.) G.Don [Macrosyringion longiflorum (Lam.) Rothm.], 82, s, Spain, Burgos, Castrillo de la Vega, -3.77922, 41.62688, D. Pinto Carrasco, DP 11 (SALA 135639), KX958510, KX959007, KX958758; Odontites longiflorus [Macrosyringion longiflorum], 586, s, Morocco, Tanger-Tétouan, Jbel L'akraa, -5.1423, 35.1366, V. Lucía \& al., VL 82 (SALA 137638), KX958575, KX959072, KX958823; Odontites longiflorus [Macrosyringion longiflorum], 587, s, Morocco, TangerTétouan, Jbel L’akraa, -5.1423, 35.1366, V. Lucia \& al., VL 82 (SALA 137638), KX958576, KX959073, KX958824; Odontites longiflorus [Macrosyringion longiflorum], 588, s, Spain, Soria, Aldehuela de Periañez, -2.34517, 41.81283, D. Pinto Carrasco, DP 851 (SALA 137313), KX958577, KX959074, KX958825; Odontites longiflorus [Macrosyringion longiflorum], 589, s, Spain, Soria, Aldehuela de Periañez, -2.34517, 41.81283, D. Pinto Carrasco, DP 851 (SALA 137313), KX958578, KX959075, KX958826; Odontites longiflorus [Macrosyringion longiflorum], 590, s, Spain, Segovia, Ayllón, Grado del Pico, -3.23325, 41.31703, D. Pinto Carrasco, DP 898 (SALA 137290), KX958579, KX959076, KX958827; Odontites longiflorus [Macrosyringion longiflorum], 591, s, Spain, Segovia, Ayllón, Grado del Pico, -3.23325, 41.31703, D. Pinto Carrasco, DP 898 (SALA 137290), KX958580, KX959077, KX958828; Odontites longiflorus [Odontites longiflorus var. roseus A.Segura], 647, h, Spain, Soria, between Renieblas and Torretartajo, -2.4, 41.8*, A. Segura Zubizarreta, 10421, Soc. Éch. Pl. Vasc. Eur. Occid. Médit. nr. 9646 (SALA 63086), KX958636, KX959133, KX958884; Odontites longiflorus [Odontites longiflorus var. roseus], 648, h, Spain, Soria, between Renieblas and Torretartajo, -2.4, 41.8*, A. Segura Zubizarreta, 10421, Soc. Éch. Pl. Vasc. Eur. Occid. Médit. nr. 9646 (SALA 63086), KX958637, KX959134, KX958885; Odontites longiflorus [Odontites longiflorus subsp. lateritius (Charpin \& Fern.Casas) Sánchez-Gómez], 649, h, Spain, Murcia, Moratalla, pico Revolcadores, -2.27, 38.07, A. Aparicio \& al., 8807 (MA 594052), KX958638, KX959135, KX958886; Odontites luteus subsp. lanceolatus (Gaudin) P.Fourn. [Odontites lanceolatus (Gaudin) Rchb. subsp. lanceolatus], 677, h, France, Hautes-Alpes, Saint-Crépin, 6.6, 44.7*, G. Dudartre, Soc. Éch. Pl. Vasc. Eur. Occid. Médit. nr. 18422 (SALA 118684), KX958665, KX959162, KX958913; Odontites luteus subsp. lanceolatus [Odontites lanceolatus subsp. lanceolatus], 678, h, Italy, Piedmont, between Col de Tende and Coni, 7.6, 44.2*, M. Bolliger, 0-72 (MA 538540), KX958666, KX959163, KX958914; Odontites luteus subsp. lanceolatus [Odontites lanceolatus subsp. lanceolatus], 679, h, France, Hautes-Alpes, Col du Lautaret, 6.3, 45.0*, M. Bolliger \& R. Bolliger, 0-16 (MA 538542), KX958667, KX959164, KX958915; Odontites luteus subsp. lanceolatus [Odontites lanceolatus subsp. lanceolatus], O.26, h, France, Isère, Les Ougiers, 6.1, 45.0*, O. Angerer, s.n. (M), KX958742, KX959239, KX958990; Odontites luteus (L.) Clairv. subsp. luteus, 83, s, Spain, Lerida, between Puente de Montañana and Tremp, 0.77634, 42.16084, E. Rico, ER 7852 (SALA 136275), KX958511, KX959008, KX958759; Odontites luteus subsp. luteus, 84, s, Spain, Lerida, between Puente de Montañana and Tremp, 0.77634, 42.16084, E. Rico, ER 7852 (SALA 136275), KX958512, KX959009, KX958760; Odontites luteus subsp. luteus, 566, s, France, Corsica, Olmeta-di-Capocorso, between Celle and Bocca di San Ghjacintu, 9.3822, 42.7544, A. Tribsch, s.n. (SALA 137640), KX958555, KX959052, KX958803; Odontites luteus subsp. luteus, 567, s, France, Corsica, Olmeta-di-Capocorso, between Celle and Bocca di San Ghjacintu, 9.3822, 42.7544, A. Tribsch, s.n. (SALA 137640), KX958556, KX959053, KX958804; Odontites luteus subsp. luteus, 568, s, Croatia, SplitskoDalmatinska, between Brela and Gornja Brela, 16.89363, 43.40381, M. Martínez Ortega \& al., MO 5538 (SALA 137346), KX958557, KX959054, KX958805; Odontites luteus subsp. luteus, 569, s, Croatia, Splitsko-Dalmatinska, between Brela and Gornja Brela, 16.89363, 43.40381, M. Martínez Ortega \& al., MO 5538 (SALA 137346), KX958558, KX959055, KX958806; Odontites luteus subsp. luteus, 602, s, Spain, Teruel, Arbolí, 0.94110, 41.22580, D. Pinto Carrasco \& al., DP 641 (SALA 135692), KX958591, KX959088, KX958839; Odontites luteus subsp. luteus, 603, s, Spain, Teruel, Arbolí, 0.94110, 41.22580, D. Pinto 
Appendix 1. Continued.

Carrasco \& al., DP 641 (SALA 135692), KX958592, KX959089, KX958840; Odontites luteus subsp. luteus, 642, s, Spain, Albacete, Riópar, -2.39010, 38.49901, D. Pinto Carrasco \& al., DP 763 (SALA 137330), KX958631, KX959128, KX958879; Odontites luteus subsp. luteus, 643, s, Spain, Albacete, Riópar, -2.39010, 38.49901, D. Pinto Carrasco \& al., DP 763 (SALA 137330), KX958632, KX959129, KX958880; Odontites luteus subsp. luteus, 658, h, France, Var, between Riez and Sainte-Croix-du-Verdon, 6.1, 43.8*, M. Bolliger, 0-60 (MA 538314), KX958647, KX959144, KX958895; Odontites luteus subsp. luteus, 659, h, France, Var, between Moustiers-Sainte-Marie and La Palud-sur-Verdon, 6.2, 43.8*, M. Bolliger, 0-59 (MA 538312), KX958648, KX959145, KX958896; Odontites luteus subsp. luteus, 661, h, France, Var, La Garde-Freinet, 6.5, 43.3*, M. Bolliger \& R. Bolliger, 0-145 (MA 538310), KX958649, KX959146, KX958897; Odontites luteus subsp. luteus, 662, h, France, Alpes-Maritimes, Roussillon, 5.3, 43.9*, M. Bolliger, 0-68 (MA 538307), KX958650, KX959147, KX958898; Odontites luteus subsp. luteus, 663, h, France, Bouches-du-Rhône, Allauch, 5.5, 43.3*, P. Martin, Soc. Éch. Pl. Vasc. Eur. Occid. Médit. nr. 6868 (MA 303024), KX958651, KX959148, KX958899; Odontites luteus subsp. luteus, 664, h, Italy, Sardinia, Badesi, 8.9114, 41.0306, C. Aedo \& al., 9108 (MA 708621), KX958652, KX959149, KX958900; Odontites luteus subsp. luteus, 665, h, France, Corrèze, between Noailles and Cressensac, 1.5, 45.1*, M. Bolliger \& R. Bolliger, 0-7 (MA 538313), KX958653, KX959150, KX958901; Odontites luteus subsp. luteus, 666, h, Italy, Umbria, Norcia, 13.1, 42.8*, A. Pavesi, Soc. Éch. Pl. Vasc. Eur. Occid. Médit. nr. 13551 (SALA 82871), KX958654, KX959151, KX958902; Odontites luteus subsp. luteus, 667, h, Germany, Bavaria, Landkreis Neumarkt, Buchenberg, 11.7, 49.2*, N. Meyer, Soc. Éch. Pl. Vasc. Eur. Occid. Médit. nr. 19539 (SALA 119350), KX958655, KX959152, KX958903; Odontites luteus subsp. luteus, 829, s, Spain, Valladolid, Santibañez de Valcorba, -4.44673, 41.57944, D. Pinto Carrasco, DP 1018 (SALA 110042), KX958716, KX959213, KX958964; Odontites luteus subsp. luteus, 830, s, Spain, Valladolid, Santibañez de Valcorba, -4.44673, 41.57944, D. Pinto Carrasco, DP 1018 (SALA 110042), KX958717, KX959214, KX958965; Odontites luteus subsp. luteus, 831, s, Czech Republic, South Moravia, between Klentnice and Mikulov, 16.64113, 48.83663, B. Rojas-Andrés \& al., BR 187 (SALA 142123), KX958718, KX959215, KX958966; Odontites luteus subsp. luteus, 832, s, Czech Republic, South Moravia, between Klentnice and Mikulov, 16.64113, 48.83663, B. Rojas-Andrés \& al., BR 187 (SALA 142123), KX958719, KX959216, KX958967; Odontites luteus subsp. provincialis (Bolliger) J.-M.Tison. [Odontites lanceolatus subsp. provincialis Bolliger], 680, h, France, Alpes-Maritimes, Col de Ferrier, 6.9, 43.7*, M. Bolliger \& R. Bolliger, 0-13 (MA 538451), KX958668, KX959165, KX958916; Odontites luteus subsp. provincialis [Odontites lanceolatus subsp. provincialis], 681, h, France, Var, between Castellane and La Palud-sur-Verdon, 6.4, 43.8*, M. Bolliger, 0-57 (MA 538452), KX958669, KX959166, KX958917; Odontites luteus subsp. provincialis [Odontites lanceolatus subsp. provincialis], 682, h, France, Alpes-Maritimes, La Penne, 6.9, 43.9*, M. Bolliger, 0-65 (MA 538453), KX958670, KX959167, KX958918; Odontites luteus subsp. provincialis [Odontites lanceolatus subsp. provincialis], 683, h, France, Alpes-Maritimes, Col de Braus, 7.4, 43.9*, M. Bolliger, 0-70 (MA 538459), KX958671, KX959168, KX958919; Odontites luteus subsp. provincialis [Odontites lanceolatus subsp. provincialis], O.02, h, France, Alpes-Maritimes, Tinée Valley, 7.2, 43.9*, M. Bolliger, 0-69 (M), KX958721, KX959218, KX958969; Odontites maroccanus Bolliger, 578, s, Morocco, Meknès-Tafilalet, Tizi-n-Tretten, -5.03801, 33.45669, D. Pinto Carrasco \& al., DP 785 (SALA 156299), KX958567, KX959064, KX958815; Odontites maroccanus, 579, s, Morocco, Meknès-Tafilalet, Tizi-n-Tretten, -5.03801, 33.45669, D. Pinto Carrasco \& al., DP 785 (SALA 156299), KX958568, KX959065, KX958816; Odontites maroccanus, 700, h, Morocco, Meknès-Tafilalet, Ifrane, Oued Tizguit, -5.1167, 33.5528, Crespo \& al., s.n. (ABH 33424), KX958687, KX959184, KX958935; Odontites maroccanus, 701, h, Morocco, Meknès-Tafilalet, Ifrane, Oued Tizguit, -5.1167, 33.5528, Crespo \& al., s.n. (ABH 33424), KX958688, KX959185, KX958936; Odontites maroccanus, 727, h, Morocco, Meknès-Tafilalet, near Jebel Hebri, -5.15, 33.36, M.A. Mateos \& al., 4396/94 (BC 852667), KX958705, KX959202, KX958953; Odontites maroccanus, O.33, h, Morocco, Meknès-Tafilalet, Timhadit, -5.1, 33.2*, E. Jahandiez, 881 (M), KX958748, KX959245, KX958996; Odontites powellii Maire, 580, s, Morocco, Meknès-Tafilalet, Tizi-n-Tretten, -5.03961, 33.45582, D. Pinto Carrasco \& al., DP 786 (SALA 156298), KX958569, KX959066, KX958817; Odontites powellii, 581, s, Morocco, Meknès-Tafilalet, Tizi-n-Tretten, -5.03961, 33.45582, D. Pinto Carrasco \& al., DP 786 (SALA 156298), KX958570, KX959067, KX958818; Odontites powellii, 582, s, Morocco, Tanger-Tétouan, Jbel L'akraa, -5.14364, 35.13683, V. Lucía \& al., VL 83 (SALA 156300), KX958571, KX959068, KX958819; Odontites powellii, 583, s, Morocco, Tanger-Tétouan, Jbel L'akraa, -5.14364, 35.13683, V. Lucía \& al., VL 83 (SALA 156300), KX958572, KX959069, KX958820; Odontites powellii, 584, s, Morocco, Tadla-Azilal, Tizi Ait Ouirrah, -6.0186, 32.5208, A. Quintanar \& al., AQ 2119 (MA 746128), KX958573, KX959070, KX958821; Odontites powellii, 585, s, Morocco, Tadla-Azilal, Tizi Ait Ouirrah, -6.0186, 32.5208, A. Quintanar \& al., AQ 2119 (MA 746128), KX958574, KX959071, KX958822; Odontites powellii, O.11, h, Morocco, Meknès-Tafilalet, between Ifrane and Zaouïa d'Ifrane, -5.1, 33.6*, M. Bolliger \& D. Moser, 0-163 (M), KX958728, KX959225, KX958976; Odontites pyrenaeus subsp. abilianus P.Monts., 606, s, Spain, Huesca, Jaca, Bernués, -0.60, 42.49, E. Rico, ER 7746 (SALA 103068), KX958595, KX959092, KX958843; Odontites pyrenaeus subsp. abilianus, 692, h, Spain, Huesca, Jaca, monte de Larbesa, -0.55, 42.54, G. Montserrat, s.n. (SALA 23738), KX958679, KX959176, KX958927; Odontites pyrenaeus subsp. abilianus, 693, h, Spain, Huesca, Jaca, Casa de Valpregona, -0.58, 42.48, E. Rico, ER 7745 (SALA 103067), KX958680, KX959177, KX958928; Odontites pyrenaeus (Bubani) Rothm. subsp. pyrenaeus, 85, s, Spain, Lerida, Sarroca de Bellera, 0.86660, 42.36414, D. Pinto Carrasco \& al., DP 615 (SALA 135664), KX958513, KX959010, KX958761; Odontites pyrenaeus subsp. pyrenaeus, 86, s, Spain, Lerida, Sarroca de Bellera, 0.86660, 42.36414, D. Pinto Carrasco \& al., DP 615 (SALA 135664), KX958514, KX959011, KX958762; Odontites pyrenaeus subsp. pyrenaeus, 604, s, Spain, Huesca, Plan, Saravillo, 0.26438, 42.55771, E. Rico, ER 7845 (SALA 136276), KX958593, KX959090, KX958841; Odontites pyrenaeus subsp. pyrenaeus, 605, s, Spain, Huesca, Plan, Saravillo, 0.26438, 42.55771, E. Rico, ER 7845 (SALA 136276), KX958594, KX959091, KX958842; Odontites pyrenaeus subsp. pyrenaeus, O.01, h, Spain, Lerida, between El Pont de Suert and Saroca de Bellera, 0.8, 42.4*, M. Bolliger, 0-38 (M), KX958720, KX959217, KX958968; Odontites rameauanus Emb., 576, s, Morocco, Tadla-Azilal, Jebel Tarkeddid, -6.5069, 31.5464, A. Quintanar \& al., AQ 2129 (MA 746138), KX958565, KX959062, KX958813; Odontites rameauanus, 577, s, Morocco, Tadla-Azilal, Jebel Tarkeddid, -6.5069, 31.5464, A. Quintanar \& al., AQ 2129 (MA 746138), KX958566, KX959063, KX958814; Odontites recordonii Burnat \& Barbey, 138, s, Spain, Alava, Bachicabo, -3.06771, 42.77934, M. Martinez Ortega, MO 4526 (SALA 135620), KX958525, KX959022, KX958773; Odontites recordonii, 170, s, Spain, Teruel, Formiche Alto, Formiche Bajo, -0.88, 40.29, L. Delgado Sánchez \& al., LD 1020 (SALA 135630), KX958526, KX959023, KX958774; Odontites recordonii, 197, s, Spain, Valencia, El Saler, -0.32096, 39.36067, D. Pinto Carrasco \& al., DP 676 (SALA 135726), KX958527, KX959024, KX958775; Odontites recordonii, 249 , s, Spain, Teruel, Arbolí, 0.96434, 41.23127, D. Pinto Carrasco \& al., DP 642 (SALA 135693), KX958528, KX959025, KX958776; Odontites recordonii, 255, s, Spain, Zaragoza, Paracuellos de Jiloca, -1.61225, 41.32468, D. Pinto Carrasco \& al., DP 653 (SALA 135704), KX958529, KX959026, KX958777; Odontites recordonii, 301, s, Spain, Guadalajara, Fuentelviejo, -2.98810, 40.51173, D. Pinto Carrasco \& al., DP 692 (SALA 135742), KX958530, KX959027, KX958778; Odontites recordonii, O.07, h, Spain, Zaragoza, between Urriés and Ruesta, -1.1, 42.6*, M. Bolliger, 0-30 (M), KX958725, KX959222, KX958973; Odontites sillettii Brullo, Tomaselli \& Wagens., O.34, h, Italy, Apulia, Santeramo in Colle, 16.8, 40.8*, G.N. Silletti \& V. Tomaselli, s.n. (MSB), KX958749, KX959246, KX958997; Odontites vernus (Bellardi) Dumort., 668, h, Denmark, Zealand, Hundige, 12.3, 55.6*, A. Hansen, Soc. Éch. Pl. Vasc. Eur. Occid. Médit. nr. 13552 (SALA 82870), KX958656, KX959153, KX958904; Odontites vernus, 669, h, Germany, Schleswig-Holstein, Leck, Büllsbüll, 9.0, 54.8*, P. Pedersen \& al., Fl. Ger. Ex., Schl.-Hols. nr. 166 (MA 327862), KX958657, KX959154, KX958905; Odontites vernus, 670, h, Denmark, Island Fur in Limfjorden, Faerker Hede, 9.0, 56.8*, K. Larsen \& S.S. Larsen, 40738, Soc. Éch. Pl. Vasc. Eur. Occid. Médit. nr. 15514 (MA 532164), KX958658, KX959155, KX958906; Odontites vernus, 671, h, Russia, Moscow, Abramtsevo, 38.0, 56.2*, E.E. Gogina, s.n. (MA 303021), KX958659, KX959156, KX958907; Odontites vernus, 672, h, Belgium, Wallonia, Tihange (Huy), 5.3, 50.5*, M. Reekmans, 11345, Soc. Éch. Pl. Vasc. Eur. Occid. Médit. nr. 11665 (SALA 75333), KX958660, KX959157, KX958908; Odontites vernus, 673, h, France, Bas-Rhin, Auenheim, 8.0, 48.8*, A. Schneider, Soc. Éch. Pl. Vasc. Eur. Occid. Médit. nr. 9650 (SALA 63091), KX958661, KX959158, KX958909; Odontites vernus, 674, h, France, motorway Nîmes-Lyon km 111, 4.8, 44.6*, unknown, 733PV (MA 443277), KX958662, KX959159, KX958910; Odontites vernus, 675, h, Italy, Veneto, Caorle, 12.9, 45.6*, F. Cernoch, 53749 FC, Soc. Éch. Pl. Vasc. Eur. Occid. Médit. nr. 16440 (SALA 88671 ), KX958663, KX959160, KX958911; Odontites vernus, 676, h, Great Britain, Hampshire, Winchester, near Itchen Down Farm, -1.2, 51.1*, S.L. Lury, Soc. Éch. Pl. Vasc. Eur. Occid. Médit. nr. 15519 (SALA 88476), KX958664, KX959161, KX958912; Odontites vernus, 716, h, Russia, Altai Krai, Kadnikovo, 81.88878, 52.87285, S.I. Molokanov \& A.P. Schalimov, s.n. (ALTB), KX958699, KX959196, KX958947; Odontites vernus, 717, h, Russia, Khakassia, foot of a ridge Alan, 91.08460, 52.80173, A.P. Shalimov \& A.D. Djagilev, s.n. (ALTB), KX958700, KX959197, KX958948; Odontites vernus, 718, h, Russia, Altai Krai, 
Appendix 1. Continued.

Mikhailovka, east coast of lake Kulundinskoe, 79.8, 53.0*, D.A. German \& D.A. Durnikin, s.n. (ALTB), KX958701, KX959198, KX958949; Odontites vernus, 719, h, Russia, Altai Republic, near settlement Aktal, 88.87, 49.92, R.V. Kamelin \& al., ADSCH 2328 (ALTB), KX958702, KX959199, KX958950; Odontites vernus, 720, h, Mongolia, Kobdosskii, $10 \mathrm{~km}$ at South from Bulgan, 91.5, 46.0*, D.L. Belkin \& A.P. Shalimov, s.n. (ALTB), KX958703, KX959200, KX958951; Odontites vernus, 721, h, Russia, Altai Krai, between Gonokhovo and Dobraya Volya, 81.24068, 52.92590, A.I. Shmakov \& al., s.n. (ALTB), KX958704, KX959201, KX958952; Odontites vernus, O.12, h, Germany, Bavaria, Neustadt an der Waldnaab, 12.2, 49.7*, W. Lippert, 27604 (M), KX958729, KX959226, KX958977; Odontites vernus, O.29, h, USA, Maine, Aroostook County, -68.3397, 46.1247, D. Atha \& M. Lee, 2235 (M), KX958744, KX959241, KX958992; Odontites vernus, O.30, h, China, Xinjiang, Atojnagh Valley, 75.17, 38.95, U. Wündisch, 748 (MSB 147298), KX958745, KX959242, KX958993; Odontites vernus, O.31, h, Finland, Hämeenlinna, 750m SW of Vanaja church, 24.5, 61.0*, R. Lampinen, 10379 (M), KX958746, KX959243, KX958994; Odontites vernus, O.32, h, Germany, Bavaria, Landkreis Freising, Eching, 11.6, 48.3*, Plachter, s.n. (M 0248419), KX958747, KX959244, KX958995; Odontites vernus subsp. fennicus (Mark1.) Pinto-Carrasco, E.Rico \& M.M.Mart.Ort. [Odontites litoralis subsp. fennicus Mark1.], 688, h, Finland, Uusimaa, Porvoon mlk, Sundby, Karilamalm, 25.87, 60.27, U. Laine \& al., s.n. (SALA 50565), KX958675, KX959172, KX958923; Odontites vernus subsp. fennicus [Odontites litoralis subsp. fennicus], 689, h, Finland, Uusimaa, Ruotsinpyhtää, Söderby, Ropanudden, 26.53, 60.33, U. Laine \& al., s.n. (SALA 50566), KX958676, KX959173, KX958924; Odontites vernus subsp. fennicus [Odontites litoralis subsp. fennicus], 690, h, Finland, Uusimaa, Storpellinge island, istmus between Koräs and Cape Sandholmen, 25.9, 60.2*, R. Lampinen, 9302, Soc. Éch. Pl. Vasc. Eur. Occid. Médit. nr. 15511 (SALA 88468), KX958677, KX959174, KX958925; Odontites vernus subsp. fennicus [Odontites litoralis subsp. fennicus], 691, h, Finland, Varsinais-Suomi, Nauvo, Västergård, 22.0, 60.2*, R. Murto \& M. Koistinen, 3833, Soc. Éch. Pl. Vasc. Eur. Occid. Médit. nr. 15515 (SALA 88472), KX958678, KX959175, KX958926; Odontites vernus subsp. himalayicus (Pennell) PintoCarrasco, E.Rico \& M.M.Mart.Ort. [Odontites vulgaris subsp. himalayicus (Pennell) Bolliger], O.23, h, Pakistan, Kashmir, Hushe River, 76.4, 35.3*, G.L. Webster \& E. Nasir, 6290 (M), KX958739, KX959236, KX958987; Odontites vernus subsp. litoralis (Fr.) Nyman [Odontites litoralis (Fr.) Fr. subsp. litoralis], 685, h, Finland, Varsinais-Suomi, Lokalahti, 21.27, 60.72, S. Hinneri, s.n. (SALA 29309), KX958672, KX959169, KX958920; Odontites vernus subsp. litoralis [Odontites litoralis subsp. litoralis], 686, h, Finland, Varsinais-Suomi, Jungfruskär island, 21.08, 60.13, K. Alho \& al., s.n. (SALA 50567), KX958673, KX959170, KX958921; Odontites vernus subsp. litoralis [Odontites litoralis subsp. litoralis], 687, h, Finland, Varsinais-Suomi, Korppoo, Kälö Island, 21.38, 60.08, U. Laine \& al., s.n. (SALA 50445), KX958674, KX959171, KX958922; Odontites vernus subsp. serotinus Corb. [Odontites vulgaris Moench. subsp. vulgaris], 48, s, Spain, Valladolid, Aldeamayor de San Martín, -4.61, 41.52, L. Delgado Sánchez \& M. Santos Vicente, LD 908 (**SALA 110700), KX958506, KX959003, KX958754; Odontites vernus subsp. serotinus [Odontites vulgaris subsp. vulgaris], 57, s, Spain, Lugo, Samos, Renche, -7.22, 42.72, E. Rico, ER 7890 (SALA 110730), KX958508, KX959005, KX958756; Odontites vernus subsp. serotinus [Odontites vulgaris subsp. vulgaris], 339, s, Greece, Arcadia, between Trípoli and Nestáni, 22.4236, 37.5834, L. Medina \& al., LM 4132 (MA 762104), KX958531, KX959028, KX958779; Odontites vernus subsp. serotinus [Odontites vulgaris subsp. vulgaris], 340, s, Greece, Arcadia, between Trípoli and Nestáni, 22.4236, 37.5834, L. Medina \& al., LM 4132 (MA 762104), KX958532, KX959029, KX958780; Odontites vernus subsp. serotinus [Odontites vulgaris subsp. vulgaris], 440, s, Turkey, Kırklareli, Dereköy, 27.35305, 41.93761, B. Rojas-Andrés \& al., BR 39 (SALA 135613), KX958535, KX959032, KX958783; Odontites vernus subsp. serotinus [Odontites vulgaris subsp. vulgaris], 463, s, Spain, Granada, Quéntar, -3.40546, 37.23347, D. Pinto Carrasco \& al., DP 663 (SALA 135713), KX958536, KX959033, KX958784; Odontites vernus subsp. serotinus [Odontites vulgaris subsp. vulgaris], 464, s, Spain, Granada, Quéntar, -3.40546, 37.23347, D. Pinto Carrasco \& al., DP 663 (SALA 135713), KX958537, KX959034, KX958785; Odontites vernus subsp. serotinus [Odontites vulgaris subsp. vulgaris], 619, s, Ireland, County Longford, Cashel Nature Reserve, opposite to Cow Island, -7.98694, 53.58889, D. Doogue, s.n. (no voucher), KX958608, KX959105, KX958856; Odontites vernus subsp. serotinus [Odontites vulgaris subsp. vulgaris], 620, s, Ireland, County Down, North of the lighthouse at St. John's Point, $-5.65722,54.22944$, D. Doogue, s.n. (no voucher), KX958609, KX959106, KX958857; Odontites vernus subsp. serotinus [Odontites vulgaris subsp. vulgaris], 710, s, France, Aisne, Beaurieux, 3.74058, 49.39850, M. Martinez Ortega \& al., MO 6024 (SALA 142126), KX958693, KX959190, KX958941; Odontites vernus subsp. serotinus [Odontites vulgaris subsp. vulgaris], 711, s, France, Aisne, Beaurieux, 3.74058, 49.39850, M. Martínez Ortega \& al., MO 6024 (SALA 142126), KX958694, KX959191, KX958942; Odontites vernus subsp. serotinus [Odontites vulgaris subsp. vulgaris], 712, s, Germany, Rheinland-Pfalz, near Landau, 8.13750, 49.17658, M. Martínez Ortega \& al., MO 6027 (SALA 142127), KX958695, KX959192, KX958943; Odontites vernus subsp. serotinus [Odontites vulgaris subsp. vulgaris], 713, s, Germany, Rheinland-Pfalz, near Landau, 8.13750, 49.17658, M. Martínez Ortega \& al., MO 6027 (SALA 142127), KX958696, KX959193, KX958944; Odontites vernus subsp. serotinus [Odontites vulgaris subsp. vulgaris], 714, s, France, Haut-Rhin, Bergheim, 7.35202, 48.21186, M. Martínez Ortega \& al., MO 6031 (SALA 142128), KX958697, KX959194, KX958945; Odontites vernus subsp. serotinus [Odontites vulgaris subsp. vulgaris], 715, s, France, Haut-Rhin, Bergheim, 7.35202, 48.21186, M. Martínez Ortega \& al., MO 6031 (SALA 142128), KX958698, KX959195, KX958946; Odontites vernus subsp. siculus (Guss.) Sell [Odontites vulgaris subsp. siculus (Guss.) Bolliger], 348, s, Italy, Sicily, Geraci Siculo, 14.1539, 37.8803, G. Domina, s.n. (PAL 88463), KX958533, KX959030, KX958781; Odontites vernus subsp. siculus [Odontites vulgaris subsp. siculus], 349, s, Italy, Sicily, Geraci Siculo, 14.1539, 37.8803, G. Domina, s.n. (PAL 88463), KX958534, KX959031, KX958782; Odontites vernus (Bellardi) Dumort. subsp. vernus, 49, s, Spain, Segovia, Valle de Tabladillo, -3.84, 41.36, L. Delgado Sánchez \& M. Santos Vicente, LD 976 (SALA 128800), KX958507, KX959004, KX958755; Odontites vernus subsp. vernus, 530 , s, Croatia, LičkoSenjska, between Prijeboj and Ličko Petrovo Selo, 15.68401, 44.84572, M. Martínez Ortega \& al., MO 5531 (SALA 137348), KX958538, KX959035, KX958786; Odontites vernus subsp. vernus, 708, s, France, Eure, Evreux, 1.10769, 49.01655, B. Rojas-Andrés \& al., BR 158 (SALA 142120), KX958691, KX959188, KX958939; Odontites vernus subsp. vernus, 709, s, France, Eure, Evreux, 1.10769, 49.01655, B. Rojas-Andrés \& al., BR 158 (SALA 142120), KX958692, KX959189, KX958940; Odontites viscosus subsp. asturicus M.Laínz, 551, s, Spain, León, Puebla de Lillo, Isoba, -5.36313, 43.09460, D. Pinto Carrasco \& E. Rico, DP 874 (SALA 137373), KX958542, KX959039, KX958790; Odontites viscosus subsp. asturicus, 598, s, Spain, León, Puebla de Lillo, Isoba, -5.36313, 43.09460, D. Pinto Carrasco \& E. Rico, DP 874 (SALA 137373), KX958587, KX959084, KX958835; Odontites viscosus subsp. asturicus, 599, s, Spain, León, Puebla de Lillo, Isoba, -5.36313, 43.09460, D. Pinto Carrasco \& E. Rico, DP 874 (SALA 137373), KX958588, KX959085, KX958836; Odontites viscosus subsp. asturicus, 657, h, Spain, Oviedo, Lena, Tuizia de Arriba, Peña Cerreos, -5.9372, 43.0164, J. Calvo, JC 4008 (MA 790195), KX958646, KX959143, KX958894; Odontites viscosus subsp. asturicus, O.21, h, Spain, Oviedo, Lena, east of Peña Vera, -5.9, 43.0*, H. Merxmüller \& W. Lippert, 29754, Herb. Lipp. nr. 15383 (M), KX958737, KX959234, KX958985; Odontites viscosus subsp. australis (Boiss.) Jahand. \& Maire, 93, s, Spain, Granada, Güéjar Sierra, Canales, -3.47717, 37.15449, D. Pinto Carrasco \& B.N. Ariza, DP 566 (SALA 136267), KX958521, KX959018, KX958769; Odontites viscosus subsp. australis, 94, s, Spain, Granada, Güéjar Sierra, Canales, -3.47717, 37.15449, D. Pinto Carrasco \& B.N. Ariza, DP 566 (SALA 136267), KX958522, KX959019, KX958770; Odontites viscosus subsp. australis, 548, s, Morocco, Tanger-Tétouan, Jbel L’akraa, -5.14364, 35.13683, V. Lucía \& al., VL 91 (SALA 156301), KX958539, KX959036, KX958787; Odontites viscosus subsp. australis, 549, s, Spain, Toledo, Orgaz, between Marjaliza and Arisgotas, -3.92741, 39.58057, V. Lucia \& al., VL 30 (SALA 137339), KX958540, KX959037, KX958788; Odontites viscosus subsp. australis, 827, s, Spain, Zamora, Corrales del Vino, -5.71, 41.34, E. Rico, ER 7974 (SALA 135647), KX958714, KX959211, KX958962; Odontites viscosus subsp. australis, 828, s, Spain, Zamora, Corrales del Vino, -5.71, 41.34, E. Rico, ER 7974 (SALA 135647), KX958715, KX959212, KX958963; Odontites viscosus subsp. eriopodus Litard. \& Maire, 656, h, Morocco, MeknèsTafilalet, between Ifrane and Zaouïa d'Ifrane, -5.1, 33.6*, M. Bolliger \& D. Moser, 0-164 (MA 538475), KX958645, KX959142, KX958893; Odontites viscosus subsp. granatensis (Boiss.) Bolliger, 95, s, Spain, Granada, Sierra Nevada, Collado de Las Sabinas, -3.42448, 37.11694, J. Peñas de Giles, ODOGRA-G01 (**SALA 135386), KX958523, KX959020, KX958771; Odontites viscosus subsp. granatensis, 96, s, Spain, Granada, Sierra Nevada, Collado de Las Sabinas, -3.42448, 37.11694, J. Peñas de Giles, ODOGRA-G01 (**SALA 135386), KX958524, KX959021, KX958772; Odontites viscosus subsp. granatensis, 558, s, Spain, Granada, Sierra Navada, barranco del Guarnón, -3.36, 37.08, D. Pinto Carrasco \& al., DP 893 (SALA 157687), KX958547, KX959044, KX958795; Odontites viscosus subsp. granatensis, 559, s, Spain, Granada, Sierra Navada, barranco del Guarnón, -3.36, 37.08, D. Pinto Carrasco \& al., DP 893 (SALA 157688), KX958548, KX959045, KX958796; Odontites viscosus subsp. granatensis, 572, s, Spain, Granada, Sierra Nevada, barranco de Río Seco, -3.34, 37.03, J. Fuentes, s.n. (GDA 61399), KX958561, KX959058, KX958809; Odontites viscosus subsp. granatensis, 573, s, Spain, Granada, Sierra Nevada, 
Appendix 1. Continued.

barranco de Río Seco, -3.34, 37.03, J. Fuentes, s.n. (GDA 61399), KX958562, KX959059, KX958810; Odontites viscosus subsp. granatensis, 627, s, Spain, Granada, Sierra Nevada, Cerro Cañadillas, -3.42758, 37.12128, J. Peñas de Giles \& J. Lorite, JPG 130 (no voucher), KX958616, KX959113, KX958864; Odontites viscosus subsp. granatensis, 628, s, Spain, Granada, Sierra Nevada, Cerro Cañadillas, -3.42758, 37.12128, J. Peñas de Giles \& J. Lorite, JPG 130 (no voucher), KX958617, KX959114, KX958865; Odontites viscosus subsp. lusitanicus Bolliger [Odontites viscosus subsp. australis], 550, s, Portugal, Setúbal, Sesimbra, Cabo Espichel, -9.2094, 38.4141, M. Santos Vicente \& al., MS 959 (SALA 123308), KX958541, KX959038, KX958789; Odontites viscosus subsp. lusitanicus [Odontites viscosus subsp. australis], 596, s, Portugal, Setúbal, Sesimbra, Cabo Espichel, -9.1880, 38.4210, M. Santos Vicente \& al., MS 961 (SALA 123309), KX958585, KX959082, KX958833; Odontites viscosus subsp. lusitanicus [Odontites viscosus subsp. australis], 597, s, Portugal, Setúbal, Sesimbra, Cabo Espichel, -9.1880, 38.4210, M. Santos Vicente \& al., MS 961 (SALA 123309), KX958586, KX959083, KX958834; Odontites viscosus (L.) Clairv. subsp. viscosus, 552, s, Spain, Barcelona, Vilada, 1.94764, 42.12980, D. Pinto Carrasco \& al., DP 633 (SALA 135684), KX958543, KX959040, KX958791; Odontites viscosus subsp. viscosus, 600, s, Spain, Lerida, Sarroca de Bellera, 0.86659, 42.36419, D. Pinto Carrasco \& al., DP 616 (SALA 135665), KX958589, KX959086, KX958837; Odontites viscosus subsp. viscosus, 601, s, Spain, Lerida, Sarroca de Bellera, 0.86659, 42.36419, D. Pinto Carrasco \& al., DP 616 (SALA 135665), KX958590, KX959087, KX958838; Odontites viscosus subsp. viscosus, 654, h, France, Hautes-Alpes, Villar-Saint-Pancrace, Le Mélézin, 6.6, 44.9*, G. Dutartre, Soc. Éch. Pl. Vasc. Eur. Occid. Médit. nr. 18426 (SALA 118680), KX958643, KX959140, KX958891; Odontites viscosus subsp. viscosus [Odontites viscosus subsp. oscensis P.Monts.], 655, h, Spain, Huesca, Broto, Asín de Broto, -0.15, 42.53, P. Montserrat, 6135/74, Soc. Éch. Pl. Vasc. Eur. Occid. Médit. nr. 9652 (SALA 63094), KX958644, KX959141, KX958892; Odontites viscosus subsp. viscosus, 825, s, France, Bouches-du-Rhône, Palama, 5.43910, 43.37670, B. RojasAndrés \& al., BR 165 (SALA 142122), KX958712, KX959209, KX958960; Odontites viscosus subsp. viscosus, 826, s, France, Bouches-du-Rhône, Palama, 5.43910, 43.37670, B. Rojas-Andrés \& al., BR 165 (SALA 142122), KX958713, KX959210, KX958961; Odontites viscosus subsp. viscosus, O.04, h, Switzerland,Valais, Bratsch, 7.7, 46.3*, M. Bolliger, 0-3 (M), KX958723, KX959220, KX958971; Odontites viscosus (L.) Clairv., 553, s, Spain, Jaén, Cazorla, near Vadillo Castril, -2.94506, 37.92067, D. Pinto Carrasco \& al., DP 666 (SALA 135716), KX958544, KX959041, KX958792; Odontites viscosus, 554, s, Spain, Palencia, La Pernía, Piedrasluengas, -4.44626, 43.02225, D. Pinto Carrasco \& E. Rico, DP 862 (SALA 137360), KX958545, KX959042, KX958793; Odontites viscosus, 555, s, Spain, León, Cármenes, Genicera, -5.47687, 42.93688, D. Pinto Carrasco \& E. Rico, DP 877 (SALA 137376), KX958546, KX959043, KX958794; Odontites vulcanicus Bolliger, O.16, h, Morocco, Meknès-Tafilalet, Michlifene, -5.1, 33.4*, M. Bolliger \& D. Moser, 0-M3 (MA 538473), KX958732, KX959229, KX958980; Parentucellia latifolia (L.) Caruel, 631, s, Spain, Cáceres, Hervás, -5.86475, 40.25480, M. Martínez Ortega \& X. Giráldez Fernández, MO 6019 (SALA 142077), KX958620, KX959117, KX958868; Parentucellia latifolia, 632, s, Spain, Cáceres, Hervás, -5.86475, 40.25480, M. Martínez Ortega \& X. Giráldez Fernández, MO 6019 (SALA 142077), KX958621, KX959118, KX958869; Phtheirospermum japonicum (Thunb.) Kanitz, P.08, h, Russia, Primorskiy, Okeanskaya (near Vladivostok), 132.0, 43.2*, A.K. Skvortsov, s.n. (M), -, KX959248, KX958998; Pterygiella tenuisecta (Bureau \& Franch.) Pinto-Carrasco, E.Rico \& M.M.Mart.Ort. [Phtheirospermum tenuisectum Bureau \& Franch.], P.07, h, China, Yunnan, Kunming, Heilongtan Botanic Garden, 102.71, 25.08, B. Dickoré, 13906 (MSB), -, KX959247,-;

\section{(2) Sequences from GenBank}

Bartsia alpina L., GB1, JF900503.1 $1^{10}$, JF900568.1 ${ }^{10}$, JF900536.1 ${ }^{10}$; Bartsia alpina, GB2, JF900504.1 $1^{10}$, JF900569.1 $1^{10}$, JF900537. $1^{10}$; Bartsia alpina, GB3,

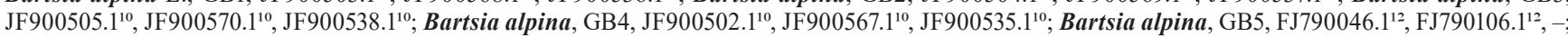

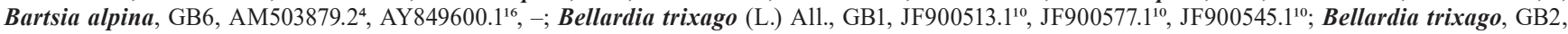

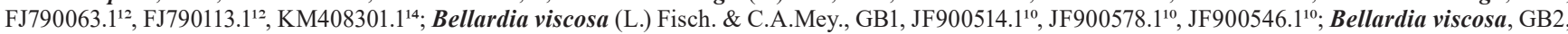

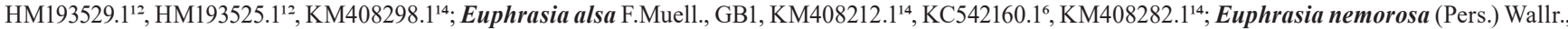

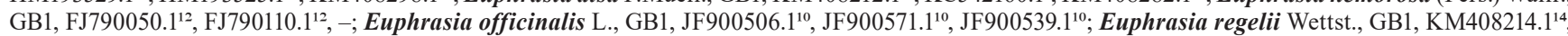

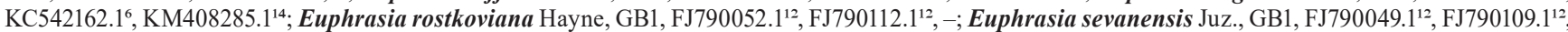

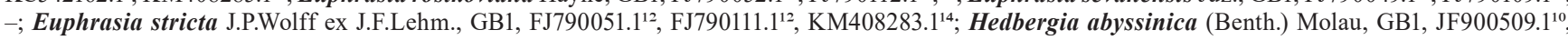

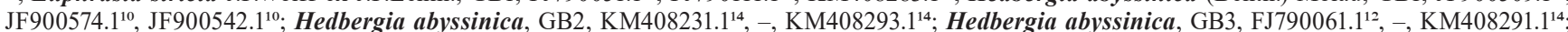

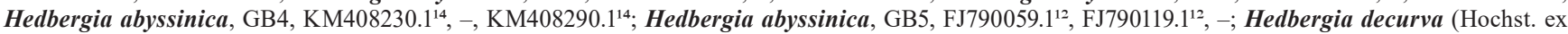
Benth.) A.Fleischm. \& Heubl, GB1, JF900511.1 $1^{10}$, JX629749.1 $1^{10}$, JF900543.1 ${ }^{10}$; Hedbergia decurva, GB2, -, -, KM408292. $1^{14}$; Hedbergia longiflora (Hochst. ex Benth.) A.Fleischm. \& Heubl subsp. longiflora, GB1, KM408232.114, -, KM408286.1 ${ }^{14}$; Hedbergia longiflora subsp. macrophylla (Hedberg) A.Fleischm.

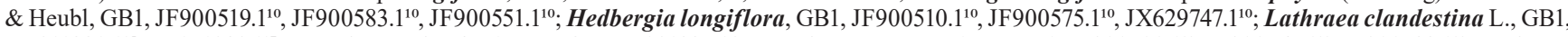

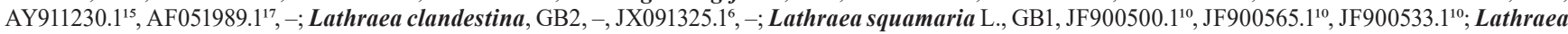

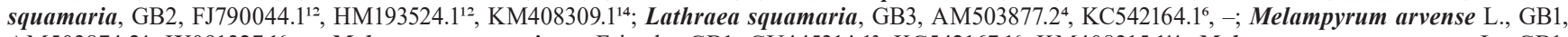

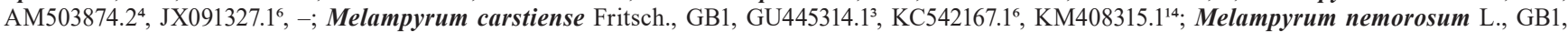

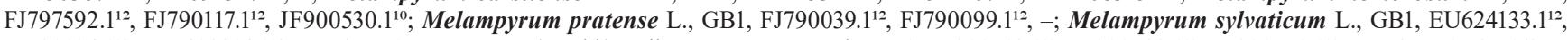

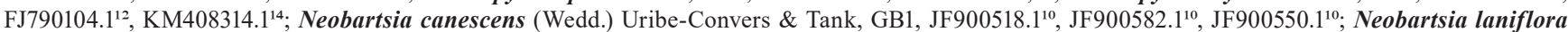

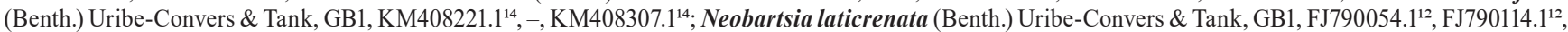
-; Neobartsia mutica (Kunth) Uribe-Convers \& Tank, GB1, JF900517.1 ${ }^{10}$, JF900581.1 ${ }^{10}$, JF900549.1 $1^{10}$; Neobartsia pedicularoides (Benth.) Uribe-Convers \& Tank, GB1, FJ790047.1 ${ }^{12}$, FJ790107.1 ${ }^{12}$,-; Neobartsia ramosa (Molau) Uribe-Convers \& Tank, GB1, KM408229.1 ${ }^{14}$, -, KM408304.1 ${ }^{14}$; Neobartsia santolinifolia (Kunth) Uribe-Convers \& Tank, GB1, KM408220.1 $1^{14},-$, KM408306.144; Neobartsia stricta (Kunth) Uribe-Convers \& Tank, GB1, KM408222.1 ${ }^{14},-$, KM408305.1 $1^{14}$; Neobartsia tenuis (Molau) Uribe-Convers \& Tank, GB1, KM408223.114, -, KM408299.14; Neobartsia thiantha (Diels) Uribe-Convers \& Tank, GB1, KM408217.114, -, KM408303.114; Nothobartsia asperrima (Link) Benedí \& Herrero, GB1, JF900508. $1^{10}, \mathrm{JF} 900573.1^{10}$, JF900541. $1^{10}$; Nothobartsia asperrima, GB2, HM193531. $1^{12}$, HM193527.1 $1^{12}$,-; Nothobartsia spicata (Ramond) Bolliger \& Molau, GB1, JX629746. $1^{10}, \mathrm{JX} 629750.1^{10}$, JX629748. $1^{10}$; Odontitella virgata

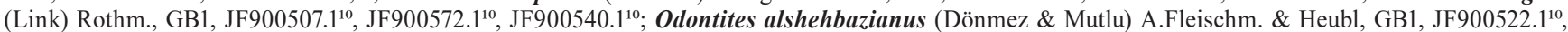

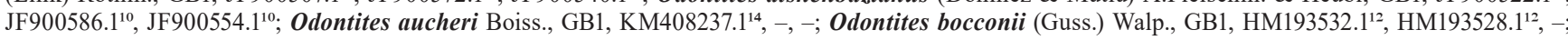
Odontites glutinosus (M.Bieb.) Benth. [Macrosyringion glutinosum (M.Bieb.) Rothm.], GB1, JF900520.1 ${ }^{10}, \mathrm{JF} 900584.1^{10}$, JF900552. ${ }^{10}$; Odontites luteus (L.)

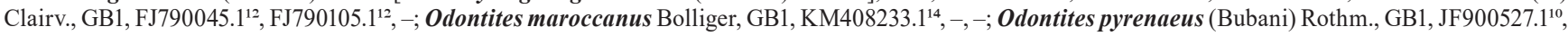

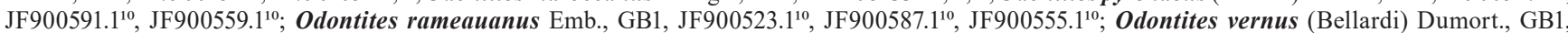

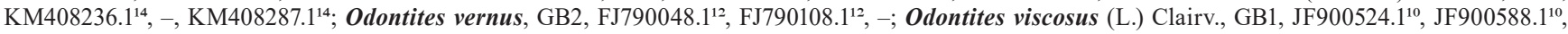

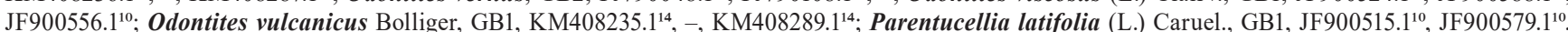

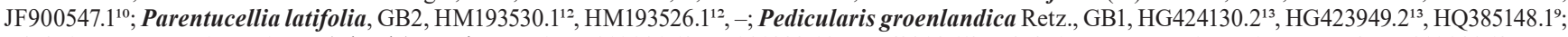
Phtheirospermum japonicum (Thunb.) Kanitz, GB1, JQ910090.12, JX091332.16, KJ563203.18; Phtheirospermum japonicum, GB2, JQ910089.12, -, -; Pseudobartsia glandulosa (Bentham) W.B.Yu \& D.Z.Li, GB1, JQ910093.12, -, -; Pseudobartsia glandulosa, GB2, GU445317.1 ${ }^{1},-,-;$ Pterygiella cylindrica Tsoong, GB1, JF746385.1 $1^{3}$, JF746407.13, -; Pterygiella cylindrica, GB2, JF746386.13, JF746408.13 , -; Pterygiella cylindrica, GB3, JF746387.13, JF746409.1 ${ }^{3}$, -; Pterygiella cylindrica var. suffruticosa (D.Y.Hong) L.N.Dong \& H.Wang, GB1, JF746399.13 , JF746419.13, -; Pterygiella cylindrica var. suffruticosa, GB2, JF746400.13 JF746420.1 ${ }^{3}$, -; Pterygiella cylindrica var. suffruticosa, GB3, JF746401.13, JF746421.1 $1^{3}$, -; Pterygiella duclouxii Franch., GB1, JF746388.1 ${ }^{3}$,

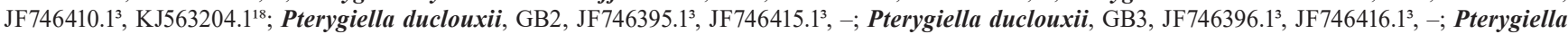
muliensis (C.Y.Wu \& D.D.Tao) Pinto-Carrasco, E.Rico \& M.M.Mart.Ort. [Phtheirospermum muliense C.Y.Wu \& D.D.Tao], GB1, JQ910091.12, -, -; Pterygiella nigrescens Oliv., GB1, JF746397.12 ${ }^{2}$ JF746417.12, -; Pterygiella nigrescens, GB2, JF746398. $1^{2}$, JF746418.12, -; Pterygiella nigrescens, GB3, JF978154.1 ${ }^{5}$, KC542177.16, -; Pterygiella parishii (Hook.f.) Pinto-Carrasco, E.Rico \& M.M.Mart.Ort. [Phtheirospermum parishii Hook.f.], GB1, JQ910092.133,-,--; Pterygiella 
Appendix 1. Continued.

tenuisecta (Bureau \& Franch.) Pinto-Carrasco, E.Rico \& M.M.Mart.Ort. [Phtheirospermum tenuisectum Bureau \& Franch.], GB1, JF746383.12,-,--; Rhinanthus

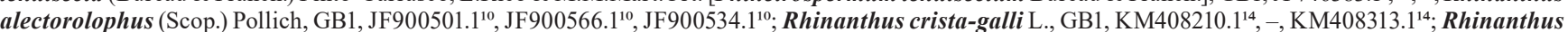

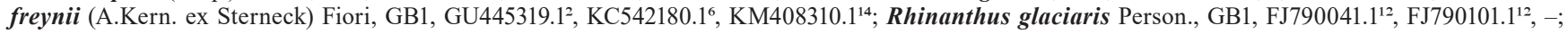

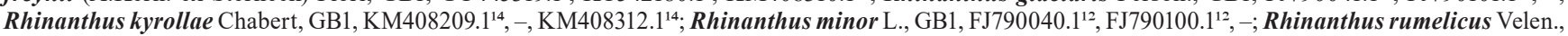

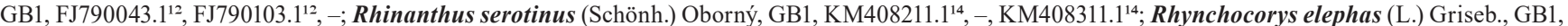

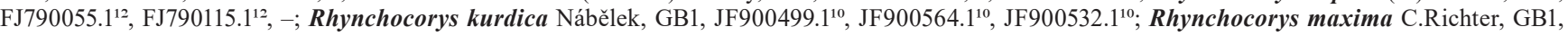

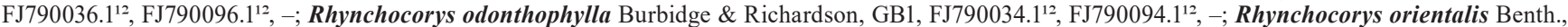

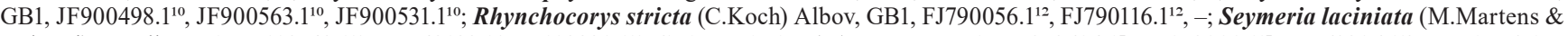

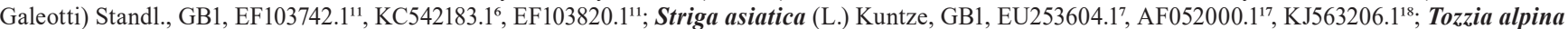

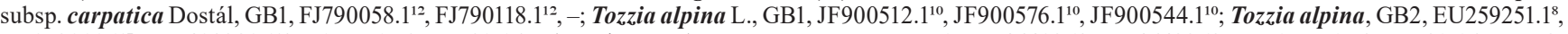
AF052001.1 $1^{17}$, KM408280.14; Xizangia bartschioides (Hand.-Mazz.) C.Y.Wu \& D.D.Tao, GB1, JF746403.12, JF746423.12, -; Xizangia bartschioides, GB2, JF746405.12, JF746424.12, -; Xizangia bartschioides, GB3, JF979021.1 $1^{5}$, JF956810.15, --

1. Dong, L.-N., Wortley, A.H., Wang, H., Lu,L. \& Li, D.-Z. Unpublished.

2. Dong, L.-N., Wortley, A.H., Wang, H., Li, D.-Z. \& Lu, L. 2011. Efficiency of DNA barcodes for species delimitation: A case in Pterygiella Oliv. (Orobanchaceae). J. Syst. Evol. 49: 189-202. https://doi.org/10.1111/j.1759-6831.2011.00124.x

3. Dong, L.-N., Wang, H., Wortley, A.H., Lu, L. \& Li, D. 2013. Phylogenetic relationships in the Pterygiella complex (Orobanchaceae) inferred from molecular and morphological evidence. Bot. J. Linn. Soc. 171: 491-507. https://doi.org/10.1111/j.1095-8339.2012.01326.x

4. Li, M., Wunder, J., Bissoli, G., Scarponi, E., Gazzani, S., Barbaro, E., Saedler, H. \& Varotto, C. 2008. Development of COS genes as universally amplifiable markers for phylogenetic reconstructions of closely related plant species. Cladistics 24: 727-745. https://doi.org/10.1111/j.1096-0031.2008.00207.x

5. Li, D.-Z., Gao, L.-M., Li, H.-T., Wang, H., Ge, X.-J., Liu, J.-Q., Chen, Z.-D., Zhou, S.-L., Chen, S.-L., Yang, J.-B., Fu, C.-X., Zeng, C.-X., Yan, H.-F., Zhu, Y.-J., Sun, Y.-Sh., Chen, S.-Y., Zhao, L., Wang, K., Yang, T. \& Duan, G.-W. 2011. Comparative analysis of a large dataset indicates that internal transcribed spacer (ITS) should be incorporated into the core barcode for seed plants. Proc. Natl. Acad. Sci. U.S.A. 108: 19641-19646. https:// doi.org/10.1073/pnas.1104551108

6. McNeal, J.R., Bennett, J.R., Wolfe, A.D. \& Mathews. S. 2013. Phylogeny and origins of holoparasitism in Orobanchaceae. Amer. J. Bot. 100: 971-983. https://doi.org/10.3732/ajb.1200448

7. Morawetz, J.J. \& Wolfe, A.D. 2009. Assessing the Monophyly of Alectra and Its Relationship to Melasma (Orobanchaceae). Syst. Bot. 34: 561-569. https://doi.org/10.1600/036364409789271281

8. Morawetz, J.J., Randle, C.P. \& Wolfe, A.D. 2010. Phylogenetic relationships within the tropical clade of Orobanchaceae. Taxon 59: 416-426.

9. Refulio-Rodriguez, N.F. \& Olmstead, R.G. 2014. Phylogeny of Lamiidae. Amer. J. Bot. 101: 287-299. https://doi.org/10.3732/ajb.1300394

10. Scheunert, A., Fleischmann, A., Olano-Marín, C., Bräuchler, C. \& Heubl, G. 2012. Phylogeny of tribe Rhinantheae (Orobanchaceae) with a focus on biogeography, cytology and re-examination of generic concepts. Taxon 61: 1269-1285.

11. Tank, D.C. \& Olmstead, R.G. 2008. From annuals to perennials: Phylogeny of subtribe Castillejinae (Orobanchaceae). Amer. J. Bot. 95: 608-625. https:// doi.org/10.3732/ajb.2007346

12. Těšitel, J., Říha, P., Svobodová, Š., Malinová, T. \& Štech, M. 2010. Phylogeny, life history evolution and biogeography of the Rhinanthoid Orobanchaceae. Folia Geobot. 45: 347-367. https://doi.org/10.1007/s12224-010-9089-y

13. Tkach, N., Ree, R.H., Kuss, P., Röser, M. \& Hoffmann, M.H. 2014. High mountain origin, phylogenetics, evolution, and niche conservatism of arctic lineages in the hemiparasitic genus Pedicularis (Orobanchaceae). Molec. Phylogen. Evol. 76: 75-92. https://doi.org/10.1016/j.ympev.2014.03.004

14. Uribe-Convers, S. \& Tank, D.C. 2015. Shifts in diversification rates linked to biogeographic movement into new areas: An example of a recent radiation in the Andes. Amer. J. Bot. 102: 1854-1869. https://doi.org/10.3732/ajb.1500229

15. Wolfe, A.D., Randle, C.P., Liu, L. \& Steiner, K.E. 2005. Phylogeny and biogeography of Orobanchaceae. Folia Geobot. 40: 115-134. https://doi. org/10.1007/BF02803229

16. Young, N.D. \& dePamphilis, C.W. 2005. Rate variation in parasitic plants: Correlated and uncorrelated patterns among plastid genes of different function. B. M. C. Evol. Biol. 5: 16. https://doi.org/10.1186/1471-2148-5-16

17. Young, N.D., Steiner, K.E. \& dePamphilis, C.W. 1999. The evolution of parasitism in Scrophulariaceae/Orobanchaceae: Plastid gene sequences refute an evolutionary transition series. Ann. Missouri Bot. Gard. 86: 876-893. https://doi.org/10.2307/2666173

18. Zhou, Q.-M., Jensen, S.R., Liu, G.-L., Wang, S. \& Li H.-Q. 2014. Familial placement of Wightia (Lamiales). Pl. Syst. Evol. 300: 2009-2017. https:// doi.org/10.1007/s00606-014-1029-5 